Cochrane Database of Systematic Reviews

\title{
Ursodeoxycholic acid for cystic fibrosis-related liver disease
} (Review)

Cheng K, Ashby D, Smyth RL

Cheng K, Ashby D, Smyth RL.

Ursodeoxycholic acid for cystic fibrosis-related liver disease.

Cochrane Database of Systematic Reviews 2017, Issue 9. Art. No.: CD000222.

DOI: 10.1002/14651858.CD000222.pub4.

www.cochranelibrary.com 
TABLE OF CONTENTS

HEADER 1

ABSTRACT

PLAIN LANGUAGE SUMMARY

SUMMARY OF FINDINGS

BACKGROUND

OBJECTIVES

METHODS

RESULTS

DISCUSSION

AUTHORS' CONCLUSIONS

ACKNOWLEDGEMENTS

REFERENCES

CHARACTERISTICS OF STUDIES

DATA AND ANALYSES

Analysis 1.1. Comparison 1: UDCA versus placebo/no additional treatment (all groups given 'conventional care'), Outcome 1: Lack of normalisation of any liver enzyme reported in the trial

Analysis 1.2. Comparison 1: UDCA versus placebo/no additional treatment (all groups given 'conventional care'), Outcome 2: Lack of normalisation of all liver enzymes reported in the trial

Analysis 1.3. Comparison 1: UDCA versus placebo/no additional treatment (all groups given 'conventional care'), Outcome 3: Lack of normalisation of 5 ' nucleotidase

Analysis 1.4. Comparison 1: UDCA versus placebo/no additional treatment (all groups given 'conventional care'), Outcome 4: Lack of normalisation of aspartate transaminase

Analysis 1.5. Comparison 1: UDCA versus placebo/no additional treatment (all groups given 'conventional care'), Outcome 5: Lack of normalisation of alanine transferase

Analysis 1.6. Comparison 1: UDCA versus placebo/no additional treatment (all groups given 'conventional care'), Outcome 6: Lack of normalisation of gammaglutamate transferase

Analysis 1.7. Comparison 1: UDCA versus placebo/no additional treatment (all groups given 'conventional care'), Outcome 7: Need for liver transplantation

Analysis 1.8. Comparison 1: UDCA versus placebo/no additional treatment (all groups given 'conventional care'), Outcome 8: Death related to liver disease

Analysis 1.9. Comparison 1: UDCA versus placebo/no additional treatment (all groups given 'conventional care'), Outcome 9: Death due to all causes

Analysis 1.10. Comparison 1: UDCA versus placebo/no additional treatment (all groups given 'conventional care'), Outcome 10: Change in weight $(\mathrm{kg})$

Analysis 1.11. Comparison 1: UDCA versus placebo/no additional treatment (all groups given 'conventional care'), Outcome 11: Development of portal hypertension

Analysis 1.12. Comparison 1: UDCA versus placebo/no additional treatment (all groups given 'conventional care'), Outcome 12: Development of complications of portal hypertension

WHAT'S NEW

HISTORY

CONTRIBUTIONS OF AUTHORS

DECLARATIONS OF INTEREST

SOURCES OF SUPPORT

DIFFERENCES BETWEEN PROTOCOL AND REVIEW

INDEX TERMS 
[Intervention Review]

\title{
Ursodeoxycholic acid for cystic fibrosis-related liver disease
}

Katharine Cheng1, Deborah Ashby², Rosalind L Smyth ${ }^{3}$

${ }^{1} \mathrm{C} /$ o Cochrane CFGD Group, Department of Women's and Children's Health, University of Liverpool, Liverpool, UK. ${ }^{2}$ School of Public Health, Imperial College London, London, UK. ${ }^{3}$ Institute of Child Health, UCL, London, UK

Contact address: Katharine Cheng, kcheng31@its.jnj.com.

Editorial group: Cochrane Cystic Fibrosis and Genetic Disorders Group.

Publication status and date: Stable (no update expected for reasons given in 'What's new'), published in Issue 4, 2021.

Citation: Cheng K, Ashby D, Smyth RL. Ursodeoxycholic acid for cystic fibrosis-related liver disease. Cochrane Database of Systematic Reviews 2017, Issue 9. Art. No.: CD000222. DOI: 10.1002/14651858.CD000222.pub4.

Copyright $@ 2017$ The Cochrane Collaboration. Published by John Wiley \& Sons, Ltd.

\begin{abstract}
A B S T R A C T

\section{Background}

Abnormal biliary secretion leads to the thickening of bile and the formation of plugs within the bile ducts; the consequent obstruction and abnormal bile flow ultimately results in the development of cystic fibrosis-related liver disease. This condition peaks in adolescence with up to $20 \%$ of adolescents with cystic fibrosis developing chronic liver disease. Early changes in the liver may ultimately result in endstage liver disease with people needing transplantation. One therapeutic option currently used is ursodeoxycholic acid. This is an update of a previous review.
\end{abstract}

\section{Objectives}

To analyse evidence that ursodeoxycholic acid improves indices of liver function, reduces the risk of developing chronic liver disease and improves outcomes in general in cystic fibrosis.

\section{Search methods}

We searched the Cochrane CF and Genetic Disorders Group Trials Register comprising references identified from comprehensive electronic database searches, handsearches of relevant journals and abstract books of conference proceedings. We also contacted drug companies and searched online trial registries.

Date of the most recent search of the Group's trials register: 09 April 2017.

\section{Selection criteria}

Randomised controlled trials of the use of ursodeoxycholic acid for at least three months compared with placebo or no additional treatment in people with cystic fibrosis.

\section{Data collection and analysis}

Two authors independently assessed trial eligibility and quality. The authors used GRADE to assess the quality of the evidence.

\section{Main results}

Twelve trials have been identified, of which four trials involving 137 participants were included; data were only available from three of the trials (118 participants) since one cross-over trial did not report appropriate data. The dose of ursodeoxycholic acid ranged from 10 to $20 \mathrm{mg} / \mathrm{kg} /$ day for up to 12 months. The complex design used in two trials meant that data could only be analysed for subsets of participants. There was no significant difference in weight change, mean difference $-0.90 \mathrm{~kg}$ ( $95 \%$ confidence interval -1.94 to 0.14 ) based on 30 participants from two trials. Improvement in biliary excretion was reported in only one trial and no significant change after treatment was shown. There were no data available for analysis for long-term outcomes such as death or need for liver transplantation. 


\section{Authors' conclusions}

There are few trials assessing the effectiveness of ursodeoxycholic acid. The quality of the evidence identified ranged from low to very low. There is currently insufficient evidence to justify its routine use in cystic fibrosis.

\section{PLAIN LANGUAGE SUMMARY}

\section{Ursodeoxycholic acid for liver disease related to cystic fibrosis}

\section{Review question}

Does ursodeoxycholic acid improve measures of liver function, reduce the risk of developing chronic liver disease and improve outcomes in general in people with cystic fibrosis?

\section{Background}

Problems with the consistency of bile (thickened) and how it flows cause liver disease in up to $20 \%$ of young people with cystic fibrosis. Bile ducts can become blocked and cause cirrhosis in one or more parts of the liver. Ursodeoxycholic acid is a naturally occurring bile acid which is taken as either a tablet or liquid to try and prevent liver disease in people with cystic fibrosis. The best response seems to be from a total dose of $20 \mathrm{mg} / \mathrm{kg} /$ day in two to three separate doses and given initially for several months but possibly indefinitely. Originally it was used to treat gallstones, but over the last few years it has been used to treat and prevent the progression of cystic fibrosis-related liver disease. This is an updated version of the review.

\section{Search date}

We last searched for evidence on 09 April 2017.

\section{Study characteristics}

We searched for trials of ursodeoxycholic acid lasting for at least three months and were able to include four trials, but data for analysis were only available from three of these. There are data from 118 participants aged between four and 32 years in this review. The dose of the drug given in the three trials with data ranged from 10 to $20 \mathrm{mg} / \mathrm{kg} /$ day. Two of these trials compared ursodeoxycholic acid to tablets with no medicine in them (placebo) and the third trial compared ursodeoxycholic acid to 'usual' treatment. The complex design of two trials meant data could not be analysed for all the participants. The trials lasted for up to 12 months, but no longer; however, one trial did report some follow-up data after nine years.

\section{Key results}

Not many of the outcomes we listed in our review were assessed; only weight gain, skinfold thickness and biliary excretion. There were no real differences between treatments for any of these outcomes. Long-term outcomes that we think are important, such as death or the need for liver transplant, were only reported in the follow-up of one trial and the information did not tell us if the people who died or needed a liver transplant had received ursodeoxycholic acid or placebo.

Current research shows that side effects of this treatment are rare, but there is not enough information about using it in the long-term to justify routinely giving it to people with cystic fibrosis. As there is no other treatment to prevent liver disease, more research on ursodeoxycholic acid is needed.

\section{Quality of the evidence}

The trials seemed to be well organised and well run, but there was not always enough information to judge them properly. While, on the whole, we do not think that any factors linked to how the trials were run would influence the results greatly, we did have some concerns that in one trial the group taking ursodeoxycholic acid were generally not as healthy at the start of the trial as the group taking placebo. Also, in another trial there were some people who withdrew and were not included in the final analysis, but no reasons for this were given. Overall, we judged the quality of the evidence we found to be low or very low. 


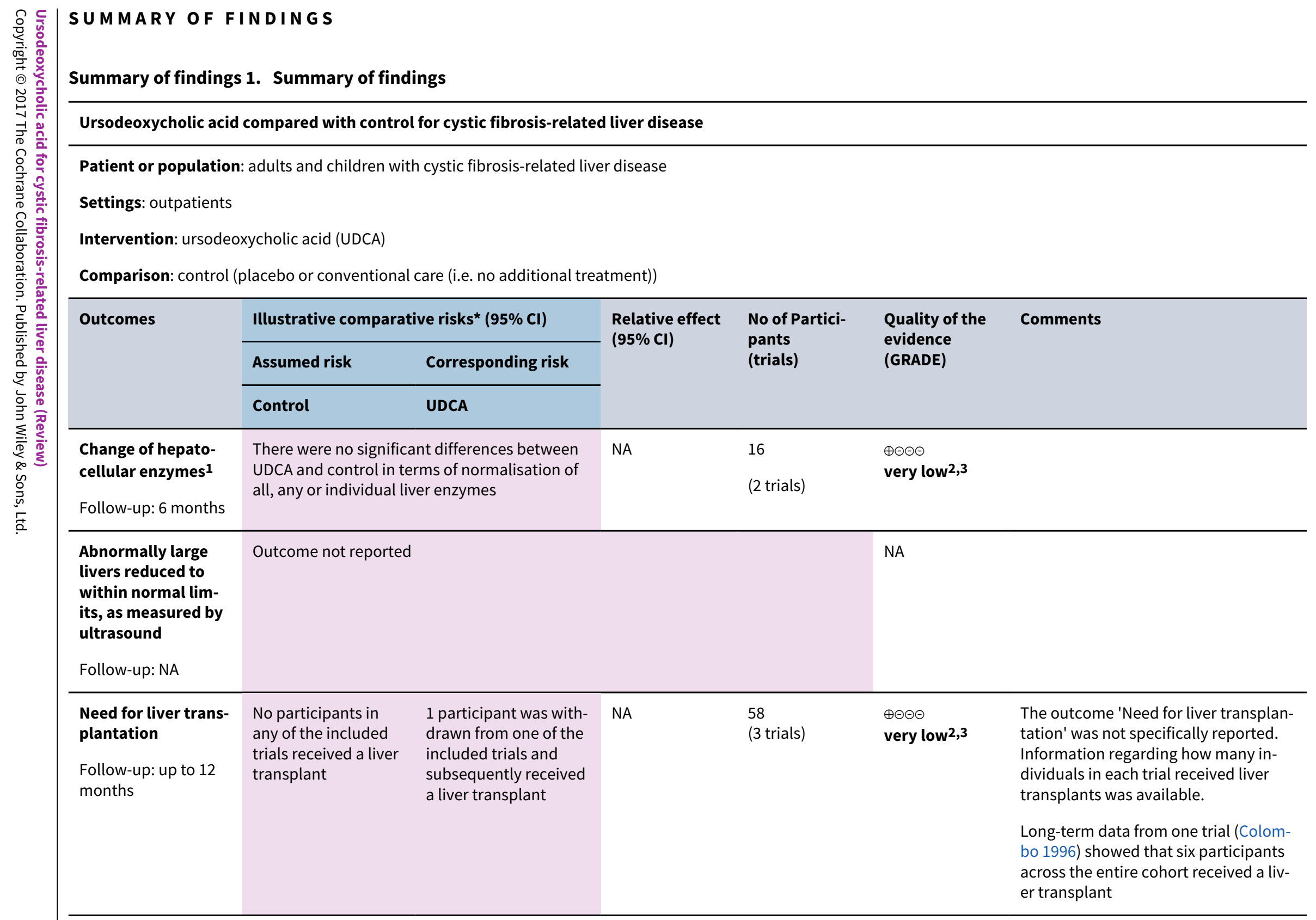




\begin{tabular}{|c|c|c|c|c|c|c|}
\hline $\begin{array}{l}\text { Mortality } \\
\text { Follow-up: up to } 12 \\
\text { months }\end{array}$ & \multicolumn{2}{|c|}{$\begin{array}{l}\text { There were no deaths in either treatment group } \\
\text { (related to liver disease or all causes) in any of } \\
\text { the trials }\end{array}$} & NA & $\begin{array}{l}58 \\
(3 \text { trials })\end{array}$ & $\begin{array}{l}\oplus \oplus \ominus \ominus \\
\text { low }^{2}\end{array}$ & $\begin{array}{l}\text { Long-term data from one trial (Colom- } \\
\text { bo 1996) showed that } 13 \text { participants } \\
\text { across the entire cohort died. }\end{array}$ \\
\hline $\begin{array}{l}\text { Nutritional status: } \\
\text { change in weight } \\
\text { (kg) } \\
\text { Follow-up: } 6 \text { months }\end{array}$ & $\begin{array}{l}\text { The mean change in } \\
\text { weight ranged across } \\
\text { control groups from } \\
0.83 \text { to } 4.88 \mathrm{~kg}\end{array}$ & $\begin{array}{l}\text { The mean change in } \\
\text { weight was in the UD- } \\
\text { CA groups was } 0.90 \mathrm{~kg} \\
\text { lower (1.94 kg lower to } \\
0.14 \mathrm{~kg} \text { higher) }\end{array}$ & NA & $\begin{array}{l}30 \\
\text { (2 trials) }\end{array}$ & $\begin{array}{l}\oplus \oplus \ominus \ominus \\
\text { low }^{2}\end{array}$ & $\begin{array}{l}\text { Minor variations (improvements) in } \\
\text { skinfold thickness and body mass per- } \\
\text { centile data were also reported in both } \\
\text { trials but no differences across treat- } \\
\text { ment groups were mentioned. }\end{array}$ \\
\hline $\begin{array}{l}\text { Development of } \\
\text { portal hypertension } \\
\text { Follow-up: } 6 \text { months }\end{array}$ & \multicolumn{2}{|c|}{$\begin{array}{l}\text { No participants in either treatment group de- } \\
\text { veloped portal hypertension or complications } \\
\text { of portal hypertension in any of the trials }\end{array}$} & NA & $\begin{array}{l}30 \\
\text { (2 trials) }\end{array}$ & $\begin{array}{l}\oplus \oplus \ominus \ominus \\
\text { low }^{2}\end{array}$ & \\
\hline $\begin{array}{l}\text { Improved abnormal } \\
\text { biliary excretion } \\
\text { Follow-up: } 6 \text { months }\end{array}$ & \multicolumn{2}{|c|}{$\begin{array}{l}\text { There was no significant change in biliary ex- } \\
\text { cretion after treatment with UDCA }\end{array}$} & NA & $\begin{array}{l}12 \\
(1 \text { trial })\end{array}$ & $\begin{array}{l}\oplus \oplus \ominus \ominus \\
\text { low } 4,5\end{array}$ & $\begin{array}{l}\text { Measured in the included trial as the } \\
\text { time (in minutes) from injection of the } \\
\text { isotope to maximal hepatic activity } \\
\text { and the percentage clearance of iso- } \\
\text { tope from the liver and biliary tree, } \\
\text { at } 45 \text { and } 60 \text { minutes compared with } \\
\text { maximal activity }\end{array}$ \\
\hline
\end{tabular}

*The basis for the assumed risk (e.g. the median control group risk across trials) is provided in footnotes. The corresponding risk (and its $95 \%$ confidence interval) is based on the assumed risk in the comparison group and the relative effect of the intervention (and its $95 \% \mathrm{Cl}$ ).

Cl: confidence interval; NA: not applicable

GRADE Working Group grades of evidence

High quality: further research is very unlikely to change our confidence in the estimate of effect.

Moderate quality: further research is likely to have an important impact on our confidence in the estimate of effect and may change the estimate.

Low quality: further research is very likely to have an important impact on our confidence in the estimate of effect and is likely to change the estimate.

Very low quality: we are very uncertain about the estimate.

1. Defined as 'Change from outside the normal range on at least one occasion to within the normal range of the method stated.'

2. Downgraded twice due to serious risk of bias: one trial was judged to be at high risk of attrition bias due to large amounts of incomplete outcome data and all included trials did not report clear details regarding trial design.

3. Downgraded once due to imprecision: very wide Cls around some effect sizes due to low event rates.

4. Downgraded once due to risk of bias: the included trial did not report clear details regarding trial design.

5. Downgraded once due to imprecision: numerical results for the outcome not available 


\section{B A C K G R O U N D}

\section{Description of the condition}

Cystic fibrosis (CF) is a common inherited disease which invariably leads to progressive lung damage. The medical management of associated chronic chest disease has improved greatly over the last 30 years leading to improvement in survival well into adult life. Clinicians are now examining ways of both treating and delaying the progression of the disease in other affected organs. Among these, CF-related liver disease is clinically the most significant hepatic complication with a large impact on morbidity and mortality (Leeuwen 2014). A recent review suggested that hepatobiliary disease is the most common non-pulmonary cause of mortality in CF (the third after pulmonary disease and transplant complications) (Parisi 2013). A recent epidemiological study reported that there was a significantly higher prevalence of CF-related hepatobiliary abnormalities in people with CF under 18 years of age and $25 \%$ of those with CF-related hepatobiliary abnormalities developed hepatobiliary disease (Bhardwaj 2009).

The mechanism of liver involvement in CF is thought to be due to a chloride channel defect causing abnormal biliary secretion which leads to the thickening of bile and the formation of plugs within the bile ducts. The resulting ductular obstruction and abnormal bile flow ultimately results in the development of bile duct irregularities inside and outside the liver and cirrhosis in one or several parts of the liver. Therefore, therapy has been directed towards attempting to improve biliary secretion and bile acid composition.

\section{Description of the intervention}

Ursodeoxycholic acid (UDCA) is a naturally occurring hydrophilic bile acid.

It is usual to take UDCA by mouth twice or three times a day, initially for several months but possibly indefinitely. Side effects are rare but diarrhoea has been reported. In 2003, the cost of six months' (24 weeks) treatment with UDCA for a 10-year old child weighing $25 \mathrm{~kg}$, at a dose of $20 \mathrm{mg} / \mathrm{kg} /$ day, was $£ 131$ (RLCH 2003). Colombo demonstrated in a dose-response study that the biochemical response to UDCA was best with a dose of $20 \mathrm{mg} / \mathrm{kg}$ / day (Colombo 1992).

\section{How the intervention might work}

In 1990, Erlinger showed that UDCA improves bile acid flow by inducing a bicarbonate-rich bile flow (Erlinger 1990). This mechanism has potential use for people with CF-related liver disease in whom the bile ducts are blocked by thick and sticky secretions. Also, UDCA is not as toxic to the liver as other primary bile acids. Initially, UDCA was used in the treatment of gallstones (Roda 1982) and more recently as a possible treatment for other chronic liver diseases such as primary biliary cirrhosis (Poupon 1991) and primary sclerosing cholangitis (Beuers 1992). Over the last few years it has been used in the treatment and prevention of progression of CF-related liver disease following the observation of its therapeutic effectiveness in these other cholestatic conditions.

\section{Why it is important to do this review}

There are a number of debates surrounding the treatment of people with CF who have liver involvement. Both early detection and assessment of progression of liver disease in CF are relatively difficult. This is because by the time liver disease is evident in a person with an enlarged liver or spleen, there is often already raised pressure in the large vein running through the liver (portal hypertension, usually an irreversible event) and end-stage liver damage (cirrhosis). At this stage the only helpful treatment may be a liver transplant. These problems mean that clinicians are faced with the dilemma of when UDCA should be commenced: early to prevent liver involvement; or later as a therapeutic option.

Another debate is how liver involvement can be evaluated. The important outcomes are death and preventing liver transplantation; other surrogate markers are often used but there are problems associated with these. Biochemical measures of liver function may not be useful because the level of abnormality does not always correlate with the extent of liver involvement (Tanner 1992). Abnormalities of these test results may also be due to an effect other than CF liver disease, such as an effect of a drug treatment (Tanner 1992). Ultrasound can be used to assess the presence and progression of liver disease (Carty 1995). It can show alterations in liver size and texture and can also be used to assess the extent and direction of blood flow in the portal vein. However, results may vary with different operators. Another technique for identifying liver disease is radioisotope scanning (hepatobiliary scintigraphy) (O'Connor 1996). Measuring the hepatic excretion of the compound 99mTc-HIDA allows an objective measurement of liver function and bile acid secretion. However, these are all intermediate outcomes and their correlations with the outcomes of death and liver transplantation are unknown.

Although UDCA is relatively inexpensive compared to other treatments taken by people with CF (see above), it is yet another treatment of many and it is important that it has been shown to be effective. Therefore, we have undertaken a systematic review assessing its effectiveness in people with CF with liver involvement. This is an updated version of earlier versions of the review (Cheng 1997; Cheng 1999; Cheng 2012; Cheng 2014).

\section{O B JECTIVES}

To analyse evidence from randomised controlled trials (RCTs) in CF that UDCA improves indices of liver function, reduces the risk of developing chronic liver disease and improves outcomes in general in CF.

\section{MET HOD S}

\section{Criteria for considering studies for this review}

\section{Types of studies}

RCTs (published or unpublished). Trials where pseudorandomisation methods are used, such as alternation, will be included.

\section{Types of participants}

Children and adults with defined CF, diagnosed clinically and by sweat test or genetic testing, including all ages, all degrees of severity of disease and any degree of liver involvement.

\section{Types of interventions}

UDCA administered orally, at any dose, given for a period of at least three months compared to a control group receiving either 
placebo or no additional therapy (i.e. both groups receiving usual CF therapy).

\section{Types of outcome measures}

\section{Primary outcomes}

1. Change of hepatocellular enzymes from outside the normal range on at least one occasion to within the normal range of the method stated

2. Abnormally large livers reduced to within normal limits, as measured by ultrasound

3. Need for liver transplantation

\section{Secondary outcomes}

1. Mortality

2. Weight gain, body mass index, $z$ score (a measure of nutritional status, where weight is expressed as a percentage of ideal for height and then compared to the standard deviation for the population (Frisancho 1990)) and other indices of nutritional improvement, if reported

3. Development of portal hypertension shown by an enlarged spleen (increased by at least 15\%), direction of portal vein flow, portal vein flow velocity, oesophageal varices (using ultrasound) or the complications of portal hypertension - these may include haematemesis (vomiting blood), reduction in platelet count or a reduction in white cell count

4. Improved abnormal biliary excretion as documented by isotope scanning (hepatic scintigraphy)

\section{Search methods for identification of studies}

We searched for all relevant published and unpublished trials without restrictions on language, year or publication status.

\section{Electronic searches}

Relevant trials were identified from the Group's Cystic Fibrosis Trials Register using the terms liver AND ursodeoxycholic acid.

The Cystic Fibrosis Trials Register is compiled from electronic searches of the Cochrane Central Register of Controlled Trials (CENTRAL) (updated each new issue of the Cochrane Library), weekly searches of MEDLINE, a search of Embase to 1995 and the prospective handsearching of two journals - Pediatric Pulmonology and the Journal of Cystic Fibrosis. Unpublished work is identified by searching the abstract books of three major cystic fibrosis conferences: the International Cystic Fibrosis Conference; the European Cystic Fibrosis Conference and the North American Cystic Fibrosis Conference. For full details of all searching activities for the register, please see the relevant section of the Cochrane Cystic Fibrosis and Genetic Disorders Group's website.

Date of the most recent search of the Group's Cystic Fibrosis Trials Register: 09 April 2017.

The authors searched clinicaltrials.gov (https://clinicaltrials.gov/) and WHO ICTRP http://apps.who.int/trialsearch/ using the terms 'cystic fibrosis' AND 'ursodeoxycholic acid'.

Date of the most recent search: 13 April 2017.

\section{Searching other resources}

Reference sections of any trials identified were checked for any further RCTs. In addition we undertook full text searching of the Journal of Pediatrics from 1988 to 1995 . We also contacted the pharmaceutical companies that market UDCA: Hoechst Marion Roussel (Destolit ${ }^{\circledR}$ ) and Consolidated Chemicals Ltd (Ursofalk ${ }^{\circledR}$ ).

\section{Data collection and analysis}

\section{Selection of studies}

The two authors ( $\mathrm{KC}$ and RS) independently applied the inclusion criteria to all potential reports.

\section{Data extraction and management}

We attempted to extract data from each RCT from the text, tables and figures. We recorded data on the number of participants with each outcome event, by allocated group, irrespective of compliance and whether or not the participant was later thought to be eligible or otherwise excluded from treatment or follow up. For continuous outcomes we recorded the mean change from baseline for each group and standard error or standard deviation.

\section{Assessment of risk of bias in included studies}

In order to assess the risk of bias in the included trials, we considered such aspects as generation of randomisation sequence and allocation concealment. If we regarded these as adequate then there was a low risk of bias to the trial; if we regarded these as inadequate, then there was a high risk of bias to the trial; and if they were considered unclear then the risk of bias was unclear too. We also considered the degree of blinding and the risk of bias increased as the number of people blinded to the intervention decreased. We also considered other risks of bias, e.g. from selective reporting.

\section{Measures of treatment effect}

We calculated a pooled estimate of the treatment effect for each outcome across trials. For binary outcomes we calculated, where possible, the odds of an outcome among treatment-allocated participants to the corresponding odds among controls. For continuous outcomes, where data were available, we calculated a pooled estimate of treatment effect by calculating the mean difference (MD) and 95\% confidence intervals (Cls).

\section{Unit of analysis issues}

Although we did not specifically excluded cross-over trials, we were concerned about the use of a cross-over design. This was because there may be a carry-over effect of UDCA in the control arm. We did include one cross-over trial in this review (Merli 1994). The data presented in the published report appeared to be combined from both treatment periods, but the authors attempted to overcome a possible carry-over effect of UDCA by using a one-month washout period. However, we considered it appropriate to compare only the first six months of the trial, i.e. UDCA versus placebo. Data from the first period were not available in the published report but the authors kindly provided the raw data. Including data from the first period in cross-over trials in meta-analyses is not without problems. Excluding later periods loses some of the information collected. Furthermore, if data from the first period are available in published reports they are likely to represent a biased subset of trials, usually because the authors have found evidence of carryover (Elbourne 2002). 


\section{Dealing with missing data}

Where sufficient data were not available in the published reports or the abstract of the conference proceedings, the review authors attempted to contact the first and last authors of the paper.

We recorded data on the number of participants with each outcome event, by allocated group, irrespective of compliance and whether or not the participant was later thought to be eligible or otherwise excluded from treatment or follow up. This approach permits an intention-to-treat analysis.

\section{Assessment of heterogeneity}

We tested for heterogeneity between trial results using a standard $\mathrm{Chi}^{2}$ test.

\section{Data synthesis}

We analysed the data using a fixed-effect model. If, in future updates of this review, we identify a moderate to large degree of heterogeneity, we will analyse the data using a random-effects model.

\section{Subgroup analysis and investigation of heterogeneity}

For future updates, if heterogeneity is identified and there are sufficient trials included in the review, we plan to investigate heterogeneity by means of examining individuals with evidence of liver disease at randomisation separately from those without liver disease.

\section{Sensitivity analysis}

We will also examine the robustness of our results using a sensitivity analysis including and excluding trials with a high risk of bias.

\section{Summary of findings and assessment of the certainty of the evidence}

In a post hoc change in line with current Cochrane guidance, at the 2017 update we added a summary of findings table (Summary of findings 1). We selected the following seven outcomes to report (chosen based on relevance to clinicians and consumers).

1. Change of hepatocellular enzymes from outside the normal range on at least one occasion to within the normal range of the method stated

2. Abnormally large livers reduced to within normal limits, as measured by ultrasound

3. Need for liver transplantation

4. Mortality

5. Nutritional status

6. Development of portal hypertension

7. Improved abnormal biliary excretion

We determined the quality of the evidence using the GRADE approach; and downgraded evidence in the presence of a high risk of bias in at least one trial, indirectness of the evidence, unexplained heterogeneity or inconsistency, imprecision of results, high probability of publication bias. We downgraded evidence by one level if they considered the limitation to be serious and by two levels if very serious.

\section{RES U L T S}

\section{Description of studies}

\section{Results of the search}

Twelve trials have been identified as potentially relevant. Four trials were included (Colombo 1996; Lepage 1997; Merli 1994; O'Brien 1992) and eight trials were excluded (Bittner 1989; Colombo 1992; Kapustina 2000; Narckewicz 1994; NCT00004315; NCT00004441; Spray 2000; Van de Meeberg 1997).

\section{Included studies}

Four trials meet the inclusion criteria (Colombo 1996; Lepage 1997; Merli 1994; O'Brien 1992). One included trial is of cross-over design but from the full published paper it is unclear whether there was any washout period employed and furthermore, data are not published for the first six-month period of the trial; thus we are unable to extract appropriate data for analysis (Lepage 1997). As such, we are only able to present results from three trials (Colombo 1996; Merli 1994; O'Brien 1992).

Four trials with a total of 137 participants are included in the review, but results are only available from three trials involving a total of 118 participants (Colombo 1996; Merli 1994; O'Brien 1992). The ages of the participants ranged from 4 years to 32 years. The dose of UDCA given ranged from 10 to $20 \mathrm{mg} / \mathrm{kg} /$ day.

In three trials the comparison was with placebo (Colombo 1996; Lepage 1997; Merli 1994). In the fourth trial the comparison was with existing conventional therapy (O'Brien 1992). In three of the trials all of the participants had liver disease (Colombo 1996; Lepage 1997; O'Brien 1992), whereas in the third trial only 10 out of 51 participants had liver disease (Merli 1994).

The length of follow-up was generally short and ranged from six months (Merli 1994; O'Brien 1992) to 12 months (Colombo 1996; Lepage 1997).

Important long-term outcomes such as death or the need for liver transplant were not reported. Only two of our protocol-defined outcomes were assessed: the nutritional indices (weight gain and skinfold thickness (Merli 1994; O'Brien 1992)); and biliary excretion (O'Brien 1992).

Trial design was complicated in three trials (Colombo 1996; Lepage 1997; Merli 1994).

In the Merli cross-over trial, 51 participants were randomised to receive UDCA alone or with taurine for six months and then each treatment group was compared with a six-month placebo period (Merli 1994). The sequence of treatment and placebo was then randomised in a cross-over design. The data presented in the published report of the cross-over RCT appeared to be combined from both treatment periods. Although we had not specifically excluded cross-over trials, we were concerned about the use of a cross-over design. This was because there may be a carry-over effect of UDCA in the control arm, although the authors attempted to overcome this by using a one-month washout period. However, we considered it appropriate to compare only the first six months of the trial, i.e. UDCA versus placebo. Data from the first period were not available in the published report but the authors have kindly provided the raw data. Including data from the first period in crossover trials in meta-analyses is not without problems. Excluding later 
periods loses some of the information collected. Furthermore, if data from the first period are available in published reports they are likely to represent a biased subset of trials, usually because the authors have found evidence of carry-over (Elbourne 2002).

In a further cross-over trial we were unable to ascertain whether a washout period was employed and data were not presented for the first treatment period; we have not been able to clarify this information and have therefore decided not to present any results from this trial (Lepage 1997).

A factorial parallel design was employed in the Colombo trial (Colombo 1996). In this multicentre trial, 55 participants were randomised to receive UDCA or placebo and then each group was further randomised to receive either taurine or a second placebo. In effect, four parallel groups were studied.

In the O'Brien trial, 12 participants were randomised to UDCA or no additional therapy for six months (other than usual CF treatments, such as pancreatic enzymes and oral calorie supplements, which the UDCA group also received) (O'Brien 1992). Advanced liver disease, as documented by portal hypertension or histological features of fibrosis or cirrhosis or all three, was present in 11 out of 12 participants.

The use of taurine in two trials also complicated their design and analysis since taurine may affect liver involvement in CF (Colombo 1996; Merli 1994). Although UDCA is known to cause taurine depletion, the combined effect of UDCA and taurine on liver function is unknown.

These possible interactions and the complex trial designs caused difficulties when we considered combining the data. We have used subsets of the sample sizes given in the 'Characteristics of included studies' table so the participant numbers evaluated in the data tables and figures do not always tally with the sample sizes. In the Merli cross-over trial we decided only to use data from the first six months of the UDCA/placebo group and not use the UDCA plus taurine group (Merli 1994). This gave us data on an unbalanced number of participants in the two groups in the first six-month period: only six participants in the UDCA group and 12 participants in the control group (51 were initially randomised). In the factorial, parallel trial we decided not to use data from participants who received taurine (hence the total number of participants used in the data tables was 28 not 55) (Colombo 1996). However, only four of these 18 participants in this subset had abnormal liver enzymes at baseline.

Another issue of the Merli cross-over RCT was that although weight, height and body mass percentile were measured, we had concerns about this type of trial design (Merli 1994). We would expect there to be a period effect on variables such as weight and height and this would require more subtle analysis. Again, we decided to use data only from participants in the UDCA-alone group and from the first six months of the trial before cross over.

In 2005 , Colombo presented follow-up survival data (obtained by a data collection form sent to each centre) from the RCT that had been conducted in 1990 (Colombo 1996). Information was obtained from 53 of the original 55 participants (two were lost to follow-up) for a median total period of follow-up of 13.6 years; follow-up data for the whole cohort were presented, not by randomised group. The majority of the trial participants had continued open UDCA therapy after the end of the trial (median daily dose $666 \mathrm{mg}$ ).

\section{Excluded studies}

Eight trials were excluded in total. Three trials were excluded because they did not include a placebo arm or a 'no UDCA' arm (Colombo 1992; NCT00004441; Van de Meeberg 1997). One trial was not an RCT (Narckewicz 1994). Two trials were of insufficient duration; in one the duration of follow up was only six weeks (Bittner 1989) and in the final cross-over trial each treatment arm lasted four weeks (NCT00004315). Two trials were only published as abstracts (no full papers) with insufficient detail to confirm they meet the inclusion criteria; given the age of the abstracts, it is unlikely that any further publications relating to this trial will be forthcoming and therefore the trials have been excluded (Kapustina 2000; Spray 2000).

\section{Risk of bias in included studies}

\section{Allocation}

All four trials were described as randomised, but only one trial stated the method used (Colombo 1996). We therefore judged the Colombo trial to have a low risk of bias (Colombo 1996), and the remaining three trials to have an unclear risk of bias (Lepage 1997; Merli 1994; O'Brien 1992).

Two trials described how allocation was concealed and these were judged to be adequate and hence have a low risk of bias (Colombo 1996; O'Brien 1992). The remaining two trials did not discuss allocation concealment and so were judged to have an unclear risk of bias (Lepage 1997; Merli 1994).

\section{Blinding}

One of the trials was described as double-blinded and we judged this to have a low risk of bias (Colombo 1996). In the Merli trial, glucose tablets were used as the placebo, so it is probable, although not explicitly stated, that the participants at least were blinded to whether they were in the treatment or control group, due to this uncertainty we judged this to have an unclear risk of bias (Merli 1994). The Lepage trial did not describe the placebo or any other aspect of blinding so it was not possible to ascertain whether the participants or the trial personnel were blinded to treatment groups and this trial was also judged to have an unclear risk of bias (Lepage 1997). It was not possible to blind the O'Brien trial to participants or clinicians since the participants either received UDCA or no additional treatment, it was not discussed whether outcome assessors were blinded; and we therefore judged this trial to have a unclear risk of bias (O'Brien 1992).

\section{Incomplete outcome data}

An intention-to-treat analysis was performed in two trials (low risk of bias) (Colombo 1996; O'Brien 1992). In one trial 51 participants were initially recruited, but nine subsequently withdrew (Merli 1994). These participants were not followed up and were not included in the analysis; data from a further two participants were identified as being lost when the raw data were provided (high risk of bias). In the fourth trial six out of 19 participants withdrew; reasons were given for all six (unclear risk of bias) (Lepage 1997). 


\section{Other potential sources of bias}

In the Colombo trial the characteristics of the two groups were not equal at baseline; the paper states that all five participants with oesophageal varices and seven out of eight participants with abnormal serum bilirubin levels at entry were allocated to the UDCA group (high risk of bias) (Colombo 1996). One cross-over trial does not clearly report whether there was any washout period and data are not published for the first six-month period of the trial (unclear risk of bias) (Lepage 1997). For the remaining two trials no other potential sources of bias were identified (low risk) (Merli 1994; O'Brien 1992).

\section{Effects of interventions}

\section{See: Summary of findings 1 Summary of findings}

The authors of the two six-month trials have kindly provided us with raw data (personal communication) (Merli 1994; O'Brien 1992). Where possible we have entered quantitative data, but the use of complicated trial designs has meant that we have had to use subsets of small sample sizes. In one cross-over trial it is unclear whether there was any washout period employed and data are not published for the first six-month period of the trial; therefore while we have listed the trial as included, we are not able to present any results as we are unable to extract appropriate data (Lepage 1997).

\section{Primary outcomes}

\section{Reduction of raised hepatocellular enzymes to within normal range of the method stated}

We wished to examine the effect of UDCA on abnormal liver biochemistry by comparing the numbers of participants in both groups whose liver enzymes fell to within the normal range of the method stated at various time points. This was not reported as an outcome measure in any of the three RCTs but, serving as a proxy for this, the improvement in abnormalities of liver function was measured in all three RCTs. Raw data were available from two of the RCTs to enable us to examine this outcome (personal communication) (Merli 1994; O'Brien 1992). We assessed this outcome in three different ways (all with a very low quality of evidence): normalisation of any liver enzyme reported, odds ratio (OR) 0.09 (95\% Cl 0.01 to 1.24) (Analysis 1.1); normalisation of all liver enzymes reported (OR not estimable as there were no participants in either of the two trials with all enzymes normalised) (Analysis 1.2); and normalisation of individual liver enzymes (OR less than one for three out of four enzymes but the Cls were very wide) (Analysis 1.3; Analysis 1.4; Analysis 1.5; Analysis 1.6). For aspartate transaminase the OR was greater than one, again with a wide $\mathrm{Cl}$ (Analysis 1.4).

\section{Reduction of abnormally large livers as measured by ultrasound}

The effect on liver size was not reported in any of the RCTs.

\section{Liver transplantation}

Need for liver transplantation was not specifically used as an outcome measure in any of the RCTs. However, one trial reported that one participant, who initially had multilobular cirrhosis and oesophageal varices (advanced liver involvement) and was allocated to treatment with UDCA, was subsequently withdrawn due to further deterioration of liver function (Colombo 1996). This participant proceeded to liver transplantation. However, the $\mathrm{Cl}$ of the OR generated was very wide and it was not possible to draw any conclusions about the effect of UDCA on the need for transplants (very low quality of evidence) (Analysis 1.7)

Need for liver transplantation was reported as an outcome in the long-term follow-up data from the Colombo trial (Colombo 1996). Six participants underwent liver transplantation. However, these long-term data were reported as follow up for the whole cohort, not by randomised group. Therefore, it is not possible to draw any firm conclusions about the effect of UDCA therapy on the need for liver transplantation from these data.

None of the participants in the two six-month trials required liver transplants (personal communication) (very low quality of evidence) (Merli 1994; O'Brien 1992) (Analysis 1.7).

\section{Secondary outcomes}

\section{Mortality}

Mortality was not reported in any of the RCTs (low quality of evidence), but there were no deaths in the two six-month trials (personal communication) (Merli 1994; O'Brien 1992) (Analysis 1.8; Analysis 1.9)

Mortality was presented in the long-term follow-up data of the Colombo trial which reported 13 deaths; none of which were due to liver disease (Colombo 1996). However, these long-term data were reported for the whole cohort, not by randomised group. Therefore, it is not possible to draw any firm conclusions about the effect of UDCA therapy on mortality from these data.

\section{Change in weight}

Nutritional indices were one of only two pre-defined outcomes reported in the published reports. Weight gain was reported in only one of the RCTs (O'Brien 1992). However, measures of weight before and after six months' treatment were reported in another RCT (Merli 1994).

Using the raw data of weight measurements before and after treatment or control in the two six-month trials (Merli 1994; O'Brien 1992), we calculated the weight change for each participant and then the mean and standard deviation for each trial (note: we again used only 18 out of 51 participants in the cross-over trial (Merli 1994)); MD $-0.90 \mathrm{~kg}(95 \% \mathrm{Cl}-1.94$ to 0.14$)$ (low quality of evidence) (Analysis 1.10).

Skinfold thickness was reported in two RCTs (Merli 1994; O'Brien 1992). Body mass percentile, which also takes into account the population mean weight and height rather than body mass index (weight in kilograms divided by height squared in metres), was reported in one trial (Merli 1994). The available post-treatment data (at six months) for the anthropometric outcomes reported in the Merli and O'Brien papers are presented in the table below. 
Ursodeoxycholic acid

\begin{tabular}{|c|c|c|c|}
\hline Height $(\mathrm{cm})$ & Merli 1994 & $157(12)$ & $158(12)$ \\
\hline Body mass percentile & Merli 1994 & $80.6(7)$ & $79.7(6)$ \\
\hline \multirow[t]{2}{*}{ Triceps skinfold thickness (mm) } & Merli 1994 & $6.5(2.1)$ & $6.8(2.3)$ \\
\hline & O'Brien 1992 & $10.0(6.13)$ & $12.1(5.64)$ \\
\hline Subscapular skinfold thickness (mm) & O'Brien 1992 & $8.6(2.94)$ & $9.1(4.41)$ \\
\hline \multirow[t]{2}{*}{ Mid-arm muscle circumference $(\mathrm{cm})$} & Merli 1994 & $19.8(3.6)$ & $20.0(3.6)$ \\
\hline & O'Brien 1992 & $21.5(3.19)$ & $22.5(1.96)$ \\
\hline
\end{tabular}

*O'Brien 1992 originally presented data as mean and standard error. Standard errors were converted to standard deviations for this table.

Merli additionally stated in the published paper that "Parameters of fat deposits (TSF, BSF, SSF, ISF) and lean body mass (MAMC) showed minor variations in both groups and were not influenced by either treatment" (Merli 1994). O'Brien stated that "... weight gain was associated with minor improvements in the measured anthropometric parameters, i.e. mid-upper arm circumference, subscapular skinfold thickness and triceps skinfold thickness in the control group and mid upper arm circumference and subscapular skinfold thickness in the treatment group. Only the improvement in triceps skinfold thickness observed in the control group reached statistical significance" (O'Brien 1992).

\section{Development of portal hypertension (raised pressure in the vein running through the liver) or its complications}

These were not reported as outcome measures in any of the RCTs. However, it was confirmed (personal communication) that in the two six-month follow-up RCTs portal hypertension did not develop in any of the participants (low quality of evidence) (Merli 1994; O'Brien 1992) (Analysis 1.11; Analysis 1.12).

\section{Improvement of biliary excretion}

This outcome was reported in only one trial (O'Brien 1992). The original trial investigators measured the time (in minutes) from injection of the isotope to maximal hepatic activity and the percentage clearance of isotope from the liver and biliary tree, at 45 and 60 minutes compared with maximal activity. No significant changes in biliary excretion occurred after treatment with UDCA (low quality of evidence).

\section{DISCUSSION}

This systematic review was first conducted in 1995 and over the intervening 22 years, no new meaningful clinical trial data have become available to change the original conclusions.

\section{Summary of main results}

This first systematic review on the effectiveness of ursodeoxycholic acid (UDCA) in cystic fibrosis (CF) highlights the paucity of randomised controlled trials (RCTs). There have been no RCTs investigating UDCA for preventing the development of liver disease in people with CF. Disappointingly, the few RCTs carried out have not adequately examined our pre-defined outcome measures, but they do provide important preliminary information which requires further evaluation. There was considerable variation in the outcome measures examined in the three RCTs and in the time points at which they were measured.

This review has shown the absence of any significant effects of UDCA treatment on people with CF, apart from a slight effect on the surrogate endpoint of reduction of raised liver enzymes to normal. The information received from the authors of the six-month trials showed that no participants died, needed liver transplants or developed portal hypertension (Merli 1994; O'Brien 1992). However, these are short-term trials and there is insufficient evidence to show that UDCA improves survival or reduces the need for liver transplantation. We failed to show a significant effect of UDCA on weight change; but this is not the most appropriate way of assessing change in nutritional status (see below). The only trial that assessed the effect of UDCA on biliary excretion failed to demonstrate any significant change after treatment (O'Brien 1992).

Although in our quantitative analysis we excluded data on participants who also received taurine, we will briefly mention individual trial results. The Merli trial showed that a six-month period of UDCA with or without taurine did not significantly affect the nutritional status (Merli 1994), whilst Colombo failed to show an effect of UDCA on liver enzymes (Colombo 1996).

\section{Overall completeness and applicability of evidence}

It is difficult to draw any meaningful conclusions from these results which are taken from small numbers of participants. Furthermore, several clinically meaningful outcomes, such as portal hypertension, liver transplantation and survival were not assessed. A number of surrogate endpoints have been reported; however, we cannot be sure that these actually correlate with important endpoints. For example, there is no evidence of a clear correlation between the serum level of hepatocellular enzymes and the degree of liver disease.

Change in weight is not the most appropriate way of assessing any change in nutritional status. This is because we would expect 
children to gain weight over time, but expect the weight of adults to remain stable. It would be more appropriate to use indices such as body mass index or weight for height as a $\mathrm{z}$ score (where weight is expressed as a percentage of ideal for height and then compared with the standard deviation for the population).

In this review we have included trials with a non-homogenous population (Merli 1994) and have, therefore, considered both possible preventative and therapeutic effects of UDCA in the same review. As we cannot be sure how raised levels of certain liver enzymes correlate with liver involvement (or whether absence of raised enzymes indicates a lack of liver involvement), we decided that we would lose important information if this trial were excluded.

\section{Quality of the evidence}

Although we had not specifically excluded cross-over trials, we were concerned about the use of a cross-over design. This was because there may be a carry-over effect of UDCA in the control arm, although the authors of the included cross-over trial attempted to overcome this problem by using a one-month washout period. However, we considered it appropriate to compare only the first six months of the trial, i.e. UDCA versus placebo.

We were only able to perform a limited quantitative meta-analysis due to the lack of data on clinically relevant endpoints and the different time points at which outcomes were measured. However, this systematic review provides an important summary of the information currently available from RCTs on the use of UDCA. This information may be used to inform the design of subsequent RCTs.

Overall, the quality of the evidence identified ranged from low to very low (Summary of findings 1 ).

\section{Potential biases in the review process}

We have undertaken comprehensive searches, including attempts to source unpublished data, to ensure that we have not failed to identify any potentially eligible RCTs. The authors have independently assessed the search results and extracted data in order to minimise any possible errors.

\section{Agreements and disagreements with other studies or reviews}

We have been unable to find any other similar reviews of UDCA in CF or any further studies other than the ones we have already included or excluded.

Although UCDA is often used for the prevention or treatment of CF-related liver disease, recommendations from guidelines are inconsistent and not based on robust evidence (CF Trust 2011; CF Trust 2016; Debray 2011; Sokol 1999).

\section{AUTHORS' CONCLUSIONS}

\section{Implications for practice}

Although UDCA is relatively inexpensive compared to other CF treatments, it would need to be taken on a long-term basis if it is effective. If it is ineffective then the resources saved by not using it could be used for other aspects of CF care.

Evidence of the effectiveness of UDCA is inconclusive. Routine use of UDCA in people with CF cannot, therefore, be justified. However, in view of these important preliminary results and because of the lack of any other effective intervention to prevent or treat CFrelated liver disease, it is essential that a large multicentre RCT of UDCA in people with CF is undertaken.

\section{Implications for research}

The results of this systematic review indicate that there is an urgent need for a well-designed, adequately powered, multicentre RCT assessing the effectiveness of UDCA by measuring clinically relevant end points over years rather than months. Ideally a parallel trial, not a cross-over trial, should be undertaken. However, as there is insufficient evidence to indicate that UDCA is effective in $\mathrm{CF}$, it is not possible to suggest how long it should be given, but long-term end points need to be assessed. Future trials should define the target population clearly, with separate trials for those without clinically detectable liver disease (the preventative effect) and those with liver disease (the therapeutic effect). In view of the problems of defining and assessing progression of liver involvement as well as the problem that by the time liver involvement is detected, it is too advanced for treatment, we suggest that the former is carried out first.

Although we have not been able to perform a formal meta-analysis, the RCTs we have identified show important preliminary results.

\section{ACK N O WLEDGEMENTS}

This review was made possible by researchers who kindly provided data and made comments. These include: Sharon O' Brien, Central Middlesex Hospital, London, UK; Manuela Merli, Universita degli Studi di Roma 'La Sapienza', Rome, Italy, Carla Colombo, University of Sassari, Sassary, Italy; Christine Spray, the Children's Hospital, Birmingham, UK; and Carol Seymour, St George's Hospital Medical School, London, UK. It was conducted as an activity of the Cochrane Cystic Fibrosis and Genetic Disorders Group, supported by grants from North West Region Research and Development and the Cystic Fibrosis Trust. However, these two organisations are not responsible for the contents of this review.

This latest project was supported by the National Institute for Health Research, via Cochrane Infrastructure funding to the Cochrane Cystic Fibrosis and Genetic Disorders Group. The views and opinions expressed therein are those of the authors and do not necessarily reflect those of the Systematic Reviews Programme, NIHR, NHS or the Department of Health. 


\section{R E F E R E N C E S}

\section{References to studies included in this review}

Colombo 1996 \{published and unpublished data\}

Colombo C, Allocca M, Quattrucci S, Traverso G, Farina S, Lucidi V, et al. Ursodeoxycholic acid for liver disease associated to cystic fibrosis: long-term follow-up of patients enrolled in the Italian multicenter trial. Pediatric Pulmonology 2005;40(Suppl 28):343. [CFGD REGISTER: CO8e]

Colombo C, Battezzati PM, Santini B, Lapichino L, Quattrucci S, Lucidi V, et al. Ursodeoxycholic acid (UDCA) for liver disease associated with Cystic Fibrosis (CF): a double-blind multicenter trial. In: Proceedings of the 18th European Cystic Fibrosis Conference; 1993 May 21-26; Madrid. 1993:W6.1. [CFGD REGISTER: CO8a]

* Colombo C, Battezzatti PM, Podda M, Bettinardi N, Giunta A, and the Italian Group for the study of ursodeoxycholic acid in cystic fibrosis. Ursodeoxycholic acid for liver disease associated with cystic fibrosis: A double-blind multicenter trial. Hepatology 1996;23(6):1484-90. [CFGD REGISTER: CO8c]

Colombo C, Battezzatti PM, Santini B, Lapichino L, Quattrucci S, Lucidi V, et al. Treatment with ursodeoxycholic acid for patients with cystic fibrosis and liver disease. In: Escobar H, Baquero F, Suarez L, editors(s). Clinical Ecology of Cystic Fibrosis. Elsevier Science Publishers BV, 1993:275-9. [CFGD REGISTER: CO8d]

Colombo C, Podda M, Battezzatti PM, Santini B, Lapichino L, Quattrucci S, et al. Ursodeoxycholic acid for cystic fibrosisassociated liver disease: Final report of a multicenter trial. Hepatology 1993;18:142A. [CFGD REGISTER: CO8b]

\section{Lepage 1997 \{published data only\}}

Lacaille F, Paradis K, Lenaerts C, Senechal L, Lepage G, Roy CC, et al. Ursodeoxycholic acid (UDCA) improves essential fatty acid (EFA) deficiency in cystic fibrosis. Hepatology 1993;18(4, Pt 2):271A. [CFGD REGISTER: CO13b]

* Lepage G, Paradis K, Lacaille F, Senechal L, Ronco N, Champagne J, et al. Ursodeoxycholic acid improves the hepatic metabolism of essential fatty acids and retinol in children with cystic fibrosis. Journal of Pediatrics 1997;130(1):52-8. [CFGD REGISTER: CO13a]

\section{Merli 1994 \{published and unpublished data\}}

Merli M, Bertasi S, Servi R, Diamanti S, Martino F, De Santis A, et al. Effect of a medium dose of ursodeoxycholic acid with or without taurine supplementation on the nutritional status of patients with cystic fibrosis. Journal of Pediatric Gastroenterology and Nutrition 1994;19(2):198-203. [CFGD REGISTER: CO5]

\section{O'Brien 1992 \{published and unpublished data\}}

* O'Brien S, Fitzgerald MX, Hegarty JE. A controlled trial of ursodeoxycholic acid treatment in cystic fibrosis-related liver disease. European Journal of Gastroenterology \& Hepatology 1992;4:857-63. [CFGD REGISTER: CO11a]
O'Brien S, Fitzgerald MX, Hegarty JE. Ursodeoxycholic acid treatment in cystic fibrosis related liver disease. Gut 1992;33:S14. [CFGD REGISTER: CO11b]

O'Brien SM, Campbell GR, Burke AF, Maguire OC, Rowlands BJ, Fitzgerald MX, et al. Serum bile acids and ursodeoxycholic acid treatment in cystic fibrosis-related liver disease. European Journal of Gastroenterology \& Hepatology 1996;8:477-83. [CFGD REGISTER: CO11c]

\section{References to studies excluded from this review}

Bittner 1989 \{unpublished data only\}

Bittner P, Posselt HG, Sailer T, Ott H, Magdorf K, Wahn U, et al. The effect of treatment with ursodeoxycholic acid in cystic fibrosis and hepatopathy: results of a placebo-controlled study. In: Paumgartner G, Stiehl A, Gerok W, editors(s). Bile acids as therapeutic agents: From basic science to clinical practice (Falk Symposium, Vol 58). Lancaster: Kluwer Academic Publishers, 1991:345-8. [CFGD REGISTER: CO7b]

Bittner P, Seiler T, Ott H, Posselt HG, Margdorf K, Kawinkel M. Therapeutical approach of ursodeoxycholic acid in cystic fibrosis and hepatopathy. In: Proceedings of the 16th Annual Meeting of the European Working Group for Cystic Fibrosis; 1989; Prague, Czechoslovakia. 1989:72. [CFGD REGISTER: CO7a]

Colombo 1992 \{published and unpublished data\}

* Colombo C, Crosignani A, Assaisso M, Battezzati PM, Podda M, Giunta A, et al. Ursodeoxycholic acid therapy in cystic fibrosisassociated liver disease: A dose-response study. Hepatology 1992;16(4):924-30. [CFGD REGISTER: CO4b]

Colombo C, Crosignani A, Castellani R, Balistreri WF, Setchell KDR, Giunta A. Ursodeoxycholic acid therapy for liver disease associated with cystic fibrosis. Bile Acids As Therapeutic Agents. From Basic Science to Clinical Practice. Falk Symposium 58 1991;43:349-56. [CENTRAL: 362985] [CFGD REGISTER: CO4c]

Colombo C, Setchell KDR, Podda M, Crosignani A, Assaisso ML, Giunta A. Ursodeoxycholic acid (UDCA) in CF associated liver disease (LD): A dose response study. In: Proceedings of the 17th European Cystic Fibrosis Conference; 1991 June 18-21; Copenhagen. 1991:140. [CFGD REGISTER: CO4a]

\section{Kapustina 2000 \{published data only\}}

Kapustina TJ, Kashirskaia NJ, Kapranov NI, Neudakhin EV. Effect of ursodeoxycholic acid on lipid metabolism in patients with cystic fibrosis [abstract]. In: Proceedings of the XIIIth International Cystic Fibrosis Congress; 2000 June 4-8; Stockholm. 2000:132. [CFGD REGISTER: CO14]

\section{Narckewicz 1994 \{unpublished data only\}}

Narkewicz MR, Sokol RJ, Lear JL, Wagener JS, Accurso FJ. Effect of ursodeoxycholic acid (UDCA) therapy for CF liver disease on indirect tests of hepatic function. Pediatric Pulmonology 1994;Suppl 10:342. [CFGD REGISTER: CO10] 


\section{NCT00004315 \{published data only\}}

NCT00004315. Phase II Pilot Study to compare the bioavailability of buffered, enteric-coated ursodiol with unmodified ursodiol for chronic cholestatic liver disease and cystic fibrosis-associated liver disease. ClinicalTrials.gov/show/ NCT00004315 (first received 18 October 1999).

\section{NCT00004441 \{published data only\}}

NCT00004441. Study of tauroursodeoxycholic acid for hepatobiliary disease in cystic fibrosis. ClinicalTrials.gov/show/ NCT00004441 (first received 18 October 1999).

\section{Spray 2000 \{published data only\}}

Spray C, Sinha B, Raman M, Ramani P, Weller P, Kelly D. Does ursodeoxycholic acid improve histological changes in liver disease in cystic fibrosis? Journal of Pediatric Gastroenterology and Nutrition 1998;26(5):584. [CFGD REGISTER: CO6b]

Spray C, Sinha B, Venkataraman M, Davies P, Ramani P, Weller P, et al. The role of ursodeoxycholic acid on histological changes in children with cystic fibrosis-liver disease - a prospective study. In: Proceedings of the XIIIth International Cystic Fibrosis Congress; 2000 June 4-8; Stockholm. 2000:132. [CFGD REGISTER: CO6a]

\section{Van de Meeberg 1997 \{published data only\}}

* Van de Meeberg PC, Houwen RHJ, Sinaasappel M, Heijerman HGM, Bijleveld CHMA, Vanberge-Henegouwen GP. Low-dose versus high-dose ursodeoxycholic acid in cystic fibrosis-related cholestatic liver disease. Results of a randomized study with 1-year follow-up. Scandinavian Journal of Gastroenterology 1997;32(4):369-73. [CFGD REGISTER: CO9a]

Van de Meeberg PC, VanBerge Henegouwen GP, The Dutch CFUDCA Trial Group. Long-term follow-up of low dose versus high dose ursodeoxycholic acid (UDCA) in cholestasis related to cystic fibrosis (CF). Gut 1996;39(Suppl 3):A118. [CFGD REGISTER: co9b]

\section{Additional references}

\section{Beuers 1992}

Beuers U, Spengler U, Kruis W, Aydemir U, Wiebecke B, Heldwein W, et al. Ursodeoxycholic acid for the treatment of primary sclerosing cholangitis: a placebo-controlled trial. Hepatology 1992;16(3):707-14.

\section{Bhardwaj 2009}

Bhardwaj S, Canlas K, Kahi C, Temkit M, Molleston J, Ober M, et al. Hepatobiliary abnormalities and disease in cystic fibrosis: epidemiology and outcomes through adulthood. Journal of Clinical Gastroenterology 2009;43(9):858-64. [DOI: 10.1097/ MCG.0b013e31819e8bbd]

\section{Carty 1995}

Carty H. Abdominal radiology in cystic fibrosis. Journal of Royal Society of Medicine 1995;88(Suppl 25):18-23.

\section{CF Trust 2011}

UK CF Trust. Standards for the clinical care of children and adults with cystic fibrosis in the UK. Second edition December
2011.. www.cysticfibrosis.org.uk/the-work-we-do/clinical-care/ consensus-documents (accessed 03 Aug 2017).

\section{CF Trust 2016}

UK CF Trust. Nutritional Management of Cystic Fibrosis. Second edition - September 2016. www.cysticfibrosis.org.uk/the-workwe-do/clinical-care/consensus-documents (accessed 03 Aug 2017).

\section{Debray 2011}

Debray D, Kelly D, Houwen R, Strandvik B, Colombo C. Best practice guidance for the diagnosis and management of cystic fibrosis-related liver disease. Journal of Cystic Fibrosis 2011;10 Suppl 2:529-36.

\section{Elbourne 2002}

Elbourne DR, Altman DG, Higgins JPT, Curtin F, Worthington HV, Vail A. Meta-analyses involving cross-over trials: methodological issues. International Journal of Epidemiology 2002;31(1):140-9.

\section{Erlinger 1990}

Erlinger S, Dumont M. Influence of ursodeoxycholic acid on bile secretion. In: Paumgartner G, Stiehl A, Barbara L, Roda E, editors(s). Strategies for the treatment of hepatobiliary disease. Dordrecht: Kluwer Academic, 1990:35-42.

\section{Frisancho 1990}

Frisancho AR. Anthropometric standards for the assessment of growth and nutritional status. Ann Arbor: University of Michigan Press 1990

\section{Leeuwen 2014}

Leeuwen L, Fitzgerald DA, Gaskin KJ. Liver disease in cystic fibrosis. Paediatric Respiratory Review 2014;15(1):69-74. [DOI: 10.1016/j.prrv.2013.05.001]

\section{O'Connor 1996}

O'Connor PJ, Southern KW, Bowler IM, Irving HC, Robinson PJ, Littlewood JM. The role of hepatobiliary scintigraphy in cystic fibrosis. Hepatology 1996;23(2):281-7.

\section{Parisi 2013}

Parisi GF, Di Dio G, Franzonello C, Gennaro A, Rotolo N, Lionetti $\mathrm{E}$, et al. Liver disease in cystic fibrosis: an update. Hepatitis Monthly 2013;13(8):e11215. [DOI: 10.5812/ hepatmon.11215]

\section{Poupon 1991}

Poupon RE, Balkau B, Eschwege E, Poupon R. A multicenter, controlled trial of ursodiol for the treatment of primary biliary cirrhosis. UDCA-PBC Study Group. New England Journal of Medicine 1991;324(22):1548-54.

\section{RLCH 2003}

Pharmacy Department, Royal Liverpool Children's Hospital NHS Trust. Personal communication December 2003.

\section{Roda 1982}

Roda E, Bazzoli F, Labate AM. Ursodeoxycholic acid vs chenodeoxycholic acid as cholesterol gallstone-dissolving 
agents: a comparative randomized study. Hepatology 1982;2(6):804-10.

\section{Sokol 1999}

Sokol RJ, Durie PR, Cystic Fibrosis Foundation Hepatobiliary Consensus Group. Recommendations for management of liver and biliary tract disease in cystic fibrosis. Journal of Pediatric Gastroenterology and Nutrition 1999;28:S1-13.

\section{Tanner 1992}

Tanner MS. Liver and biliary problems in cystic fibrosis. Journal of Royal Society of Medicine 1992;85(Suppl 19):20-4.

\section{References to other published versions of this review \\ Cheng 1997}

Cheng K, Smyth RL, Ashby D. Ursodeoxycholic acid in cystic fibrosis related liver disease: a systematic review. Journal of the Royal Society of Medicine 1997;90(Suppl 31):6-12.

\section{CHARACTERISTICS OF STUDIES}

Characteristics of included studies [ordered by study ID]

\section{Cheng 1999}

Cheng K, Ashby D, Smyth RL. Ursodeoxycholic acid for cystic fibrosis-related liver disease. Cochrane Database of Systematic Reviews 1999, Issue 3. Art. No: CD000222. [DOI: 10.1002/14651858.CD000222]

\section{Cheng 2012}

Cheng K, Ashby D, Smyth RL. Ursodeoxycholic acid for cystic fibrosis-related liver disease. Cochrane Database of Systematic Reviews 2012, Issue 10. Art. No: CD000222. [DOI: 10.1002/14651858.CD000222.pub2]

\section{Cheng 2014}

Cheng K, Ashby D, Smyth RL. Ursodeoxycholic acid for cystic fibrosis-related liver disease. Cochrane Database of Systematic Reviews 2014, Issue 12. Art. No: CD000222. [DOI: 10.1002/14651858.CD000222.pub3]

* Indicates the major publication for the study

Colombo 1996

\section{Study characteristics}

Methods

Multi-factorial (4 parallel groups: initial randomisation to UDCA or placebo, then taurine or second placebo randomly added to participants), centrally computer-generated list, double-blind. Multicentre, 12 centres in Italy.

Participants Inclusion criteria: diagnosis of CF (sweat test and clinically) and chronic liver disease, defined on basis of large liver, abnormal liver ultrasound showing increased liver size, abnormal pattern and irregular surface, abnormal liver enzymes (serum transaminases and gamma glutamyl transpeptidase for at least 12 months).

Participants excluded if any previous treatment with UDCA, less than 3 years, serum bilirubin over 3 $\mathrm{mg} / \mathrm{dL}$, ascites, chronic viral hepatitis, co-existing severe lung disease, previous episodes of bleeding from oesophageal varices or other complications of portal hypertension. 55 (39 male) participants. 15 in UDCA and taurine group, 15 in UDCA and placebo group, 12 in placebo and taurine group and 13 in placebo and placebo group. Age range 4 - 22 years (median 13.8 years). All 5 participants with oesophageal varices and 7 out of 8 participants with abnormal serum bilirubin levels at entry, in UDCA group.

Length of therapy: 12 months
UDCA: $10-20 \mathrm{mg} / \mathrm{kg} / \mathrm{day}$.
Taurine: $17-33 \mathrm{mg} / \mathrm{kg} /$ day.
Control: placebo.

Outcomes Measured at 12 months

Shwachman-Kulczycki score (SKS), liver enzymes (gammaglutamate transferase, 5' nucleotidase, aspartate transaminase, alanine transaminase), prealbumin, daily faecal fat excretion.

\section{Risk of bias}


Colombo 1996 (Continued)

\begin{tabular}{lll}
$\begin{array}{l}\text { Random sequence genera- } \\
\text { tion (selection bias) }\end{array}$ & Low risk & Computer-generated list. \\
\hline $\begin{array}{l}\text { Allocation concealment } \\
\text { (selection bias) }\end{array}$ & Low risk & List generated centrally. \\
\hline $\begin{array}{l}\text { Blinding (performance } \\
\text { bias and detection bias) } \\
\begin{array}{l}\text { All outcomes } \\
\text { L }\end{array}\end{array}$ & Low risk & Described as double blind \\
\hline
\end{tabular}

Incomplete outcome data $\quad$ Low risk $\quad$ An intention-to-treat analysis was performed.
(attrition bias)

All outcomes

\begin{tabular}{ll} 
Other bias $\quad$ High risk & $\begin{array}{l}\text { Group characteristics not equal at baseline - all } 5 \text { participants with oe- } \\
\text { sophageal varices and } 7 \text { out of } 8 \text { participants with abnormal serum bilirubin } \\
\text { levels at entry, in UDCA group. }\end{array}$ \\
\hline
\end{tabular}

\section{Lepage 1997}

\section{Study characteristics}

\begin{tabular}{|c|c|}
\hline Methods & $\begin{array}{l}\text { Double-blind, placebo-controlled, randomised cross-over trial } 1 \text { year duration ( } 2 \text { periods of } 6 \text { months } \\
\text { each). } \\
\text { Single centre in Canada. }\end{array}$ \\
\hline Participants & $\begin{array}{l}19 \text { (13 males; } 6 \text { girls) children with CF and liver dysfunction, aged } 7 \text { - } 17 \text { years (mean (SD) } 11.9 \text { (0.6) } \\
\text { years). } \\
6 \text { withdrawals ( } 1 \text { died, } 4 \text { moved away, } 1 \text { discontinued medication). }\end{array}$ \\
\hline Interventions & $\begin{array}{l}\text { UDCA ( } 15 \mathrm{mg} / \mathrm{kg} / \mathrm{day} \text { ) versus placebo. } \\
\text { In the absence of a } 50 \% \text { decrease of ALT or AST or both within } 2 \text { months, the dose was increased to } 30 \\
\mathrm{mg} / \mathrm{kg} \text {. } \\
\text { Participants received their usual medication, including pancreatic enzyme supplements. }\end{array}$ \\
\hline Outcomes & $\begin{array}{l}\text { Liver function tests (AST, ALT, GGT), plasma lipid levels (total fatty acids, triglycerides, cholesterol), plas- } \\
\text { ma RBP, transthyretin, retinol, retinyl ester levels. }\end{array}$ \\
\hline Notes & $\begin{array}{l}\text { Supported by a University-Industry (Jouveinal Inc.) award (UI- 0062), from the Medical Research Coun- } \\
\text { cil of Canada and by a grant from the Canadian Cystic Fibrosis Foundation. }\end{array}$ \\
\hline
\end{tabular}

\section{Risk of bias}

\begin{tabular}{lll}
\hline Bias & Authors' judgement & Support for judgement \\
\hline $\begin{array}{l}\text { Random sequence genera- } \\
\text { tion (selection bias) }\end{array}$ & Unclear risk & Paper states "randomly assigned" but gives no further details. \\
\hline $\begin{array}{l}\text { Allocation concealment } \\
\text { (selection bias) }\end{array}$ & Unclear risk & Not discussed. \\
\hline $\begin{array}{l}\text { Blinding (performance } \\
\text { bias and detection bias) }\end{array}$ & Unclear risk & Not discussed. \\
\hline
\end{tabular}


Lepage 1997 (Continued)

All outcomes

\begin{tabular}{lll}
$\begin{array}{l}\text { Incomplete outcome data } \\
\text { (attrition bias) } \\
\text { All outcomes }\end{array}$ & Unclear risk & $\begin{array}{l}6 / 19 \text { withdrew - } 1 \text { participant died, } 4 \text { moved away, and } 1 \text { discontinued his med- } \\
\text { ication. }\end{array}$ \\
\hline Other bias & Unclear risk & $\begin{array}{l}\text { Cross-over trial and data not presented for each treatment arm separately. Not } \\
\text { clear if a washout period was employed. }\end{array}$ \\
\hline
\end{tabular}

Merli 1994

\section{Study characteristics}

\begin{tabular}{l} 
Methods \\
$\begin{array}{l}\text { Cross-over design. Randomisation to UDCA or UDCA plus taurine for } 6 \text { months, then each group com- } \\
\text { pared with placebo for } 6 \text { months and sequence of treatment/placebo randomised. Placebo was glu- } \\
\text { cose. } \\
\text { Single centre. Italy. } \\
\text { Inclusion criteria: } \\
\text { 1. diagnosis of CF as documented by raised sweat chloride values and clinical symptoms; } \\
\text { 2. evidence of malnutrition as documented by body mass percentile less than or equal to 90\%; } \\
\text { 3. age over } 6 \text { years; } \\
\text { 4. good compliance with previous conventional treatment; } \\
\text { 5. no previous UDCA treatment. } \\
\text { 51 participants recruited, age range } 8 \text { - 32 years, median } 14 \text { years. } 10 \text { participants had abnormal liver } \\
\text { enzymes and of these } 2 \text { had cirrhosis and varices and } 8 \text { had enlarged liver and fibrosis at ultrasound. } \\
\text { 42 participants completed the trial, } 9 \text { dropouts (5 in UDCA group, } 4 \text { in UDCA plus taurine group) not fol- } \\
\text { lowed-up. }\end{array}$ \\
\hline
\end{tabular}

Interventions UDCA: $12 \mathrm{mg} / \mathrm{kg} /$ day for 6 months (see Methods for trial design).

Taurine: 18 - $22 \mathrm{mg} / \mathrm{kg} /$ day for 6 months.

Control: placebo (glucose) for 6 months.

\begin{tabular}{ll}
\hline Outcomes & Measured at 6 months \\
& weight, body mass percentile, triceps skinfold thickness, mid-arm-muscle circumference, albumin, AST, \\
& ALT, ALP, GGT.
\end{tabular}

ALT, ALP, GGT.

\section{Notes}

\section{Risk of bias}

\begin{tabular}{lll}
\hline Bias & Authors' judgement & Support for judgement \\
\hline $\begin{array}{l}\text { Random sequence genera- } \\
\text { tion (selection bias) }\end{array}$ & Unclear risk & Stated as randomised but no further details of method given. \\
\hline $\begin{array}{l}\text { Allocation concealment } \\
\text { (selection bias) }\end{array}$ & Unclear risk & Unclear. \\
\hline $\begin{array}{l}\text { Blinding (performance } \\
\text { bias and detection bias) } \\
\text { All outcomes }\end{array}$ & Unclear risk & $\begin{array}{l}\text { Glucose tablets given as placebo, so participants probably blinded, but not ex- } \\
\text { plicitly stated. }\end{array}$ \\
\hline
\end{tabular}


Merli 1994 (Continued)

Incomplete outcome data High risk 51 participants were initially recruited, but 9 subsequently withdrew (5 in UD-

(attrition bias)

CA group, 4 in UDCA plus taurine group). These participants were not followed

All outcomes up and were not included in the analysis. Data from a further 2 participants were identified as being lost when the raw data were provided.

\begin{tabular}{ll}
\hline Other bias $\quad$ Unclear risk $\quad$ None identified. \\
\hline
\end{tabular}

\section{O'Brien 1992}

\section{Study characteristics}

\begin{tabular}{|c|c|}
\hline Methods & $\begin{array}{l}\text { Randomisation stated - method not described. } \\
\text { Single centre. Ireland. }\end{array}$ \\
\hline Participants & $\begin{array}{l}\text { Inclusion criteria: participants with CF (diagnosed by sweat test and clinically) and with liver disease. } \\
\text { This was defined as large liver, greater than } 12 \mathrm{~cm} \text { on physical examination and/or large spleen, palpa- } \\
\text { ble on examination and confirmed by abdominal ultrasound and/ or raised liver enzymes for at least } 6 \\
\text { months (GGT above } 50 \mathrm{IU} / \mathrm{L}, 5 \text { 'nucleotidase over } 15 \mathrm{IU} / \mathrm{I} \text { ). } \\
12 \text { participants recruited. Age range } 12-42 \text { years (median } 19.5 \text { years). } 11 \text { out of } 12 \text { participants had ad- } \\
\text { vanced liver disease - portal hypertension and/or histological features of fibrosis or cirrhosis. }\end{array}$ \\
\hline
\end{tabular}

\begin{tabular}{ll}
\hline Interventions & UDCA: $20 \mathrm{mg} / \mathrm{kg} /$ day for 6 months. \\
& Control: No additional therapy. \\
\hline Outcomes & $\begin{array}{l}\text { Weight gain, triceps skinfold thickness, mid-upper arm circumference, subscapular skinfold thickness, } \\
\text { liver enzymes, biliary excretion. }\end{array}$
\end{tabular}

Notes

\section{Risk of bias}

\begin{tabular}{lll}
\hline Bias & Authors' judgement & Support for judgement \\
\hline $\begin{array}{l}\text { Random sequence genera- } \\
\text { tion (selection bias) }\end{array}$ & Unclear risk & Randomisation stated - method not described. \\
\hline $\begin{array}{l}\text { Allocation concealment } \\
\text { (selection bias) }\end{array}$ & Low risk & Sealed envelopes used. \\
\hline $\begin{array}{l}\text { Blinding (performance } \\
\text { bias and detection bias) } \\
\text { All outcomes }\end{array}$ & Unclear risk & $\begin{array}{l}\text { Control was no additional therapy so clinicians and participants could not be } \\
\text { blinded, not discussed whether outcome assessors were blinded. }\end{array}$ \\
\hline $\begin{array}{l}\text { Incomplete outcome data } \\
\text { (attrition bias) } \\
\text { All outcomes }\end{array}$ & Low risk & An intention-to-treat analysis was performed. \\
\hline $\begin{array}{l}\text { Other bias } \\
\end{array}$ & Unclear risk & None identified. \\
\hline
\end{tabular}

ALP: alkaline phosphatase

ALT: alanine transaminase

AST: aspartate transaminase

CF: cystic fibrosis

GGT: gamma glutamate transferase

IU/L: international unit per litre 
RBP: retinol binding protein

UDCA: ursodeoxycholic acid

Characteristics of excluded studies [ordered by study ID]

\begin{tabular}{ll}
\hline Study & Reason for exclusion \\
\hline Bittner 1989 & Unclear how long UDCA given for, follow up only 6 weeks. \\
\hline Colombo 1992 & Comparison of different doses of UDCA rather than with placebo or conventional therapy. \\
\hline Kapustina 2000 & $\begin{array}{l}\text { Only published as an abstract (no full paper) with insufficient detail to confirm it meets the inclu- } \\
\text { sion criteria; given the age of the abstract, it is unlikely that any further publications relating to this } \\
\text { trial will be forthcoming. }\end{array}$ \\
\hline Narckewicz 1994 & $\begin{array}{l}\text { Multi-period, multi-treatment trial, not randomised. } \\
\text { NCT00004315 }\end{array}$ \\
\hline NCT00004441 & $\begin{array}{l}\text { Not a valid comparison - active group is tauro-ursodeoxcholic acid and the comparator is ur- } \\
\text { sodeoxycholic acid. Our inclusion criteria state that the active treatment is UDCA with the control } \\
\text { group receiving either placebo or no additional therapy. }\end{array}$ \\
\hline Spray 2000 & $\begin{array}{l}\text { Only published as an abstract (no full paper) with insufficient detail to confirm it meets the inclu- } \\
\text { sion criteria; given the age of the abstract, it is unlikely that any further publications relating to this } \\
\text { trial will be forthcoming. }\end{array}$ \\
\hline Van de Meeberg 1997 & $\begin{array}{l}\text { Comparison of low dose UDCA (10 mg/kg/day) versus high dose UDCA (20 mg/kg/day) rather than } \\
\text { UDCA against placebo or no additional treatment. }\end{array}$ \\
\hline
\end{tabular}

UDCA: ursodeoxycholic acid

\section{DATA AND ANALYSES}

\section{Comparison 1. UDCA versus placebo/no additional treatment (all groups given 'conventional care')}

\begin{tabular}{|c|c|c|c|c|}
\hline Outcome or subgroup title & No. of studies & $\begin{array}{l}\text { No. of partici- } \\
\text { pants }\end{array}$ & Statistical method & Effect size \\
\hline $\begin{array}{l}1.1 \text { Lack of normalisation of any } \\
\text { liver enzyme reported in the tri- } \\
\text { al }\end{array}$ & 2 & & Odds Ratio (M-H, Fixed, 95\% Cl) & Subtotals only \\
\hline 1.1.16 months & 2 & 16 & Odds Ratio (M-H, Fixed, 95\% Cl) & $0.09[0.01,1.24]$ \\
\hline $\begin{array}{l}1.2 \text { Lack of normalisation of all } \\
\text { liver enzymes reported in the } \\
\text { trial }\end{array}$ & 2 & & Odds Ratio (M-H, Fixed, 95\% Cl) & Subtotals only \\
\hline 1.2.1 6 months & 2 & 16 & Odds Ratio (M-H, Fixed, 95\% Cl) & Not estimable \\
\hline $\begin{array}{l}1.3 \text { Lack of normalisation of } 5 \text { ' } \\
\text { nucleotidase }\end{array}$ & 1 & & Odds Ratio (M-H, Fixed, 95\% Cl) & Totals not selected \\
\hline
\end{tabular}




\begin{tabular}{|c|c|c|c|c|}
\hline Outcome or subgroup title & No. of studies & $\begin{array}{l}\text { No. of partici- } \\
\text { pants }\end{array}$ & Statistical method & Effect size \\
\hline 1.3.1 6 months & 1 & & Odds Ratio (M-H, Fixed, 95\% Cl) & Totals not selected \\
\hline $\begin{array}{l}\text { 1.4 Lack of normalisation of as- } \\
\text { partate transaminase }\end{array}$ & 2 & & Odds Ratio (M-H, Fixed, 95\% Cl) & Subtotals only \\
\hline 1.4.16 months & 2 & 14 & Odds Ratio (M-H, Fixed, 95\% Cl) & $11.00[0.43,284.30]$ \\
\hline $\begin{array}{l}\text { 1.5 Lack of normalisation of ala- } \\
\text { nine transferase }\end{array}$ & 2 & & Odds Ratio (M-H, Fixed, 95\% Cl) & Subtotals only \\
\hline 1.5.1 6 months & 2 & 12 & Odds Ratio (M-H, Fixed, 95\% Cl) & $0.41[0.04,4.01]$ \\
\hline $\begin{array}{l}\text { 1.6 Lack of normalisation of } \\
\text { gammaglutamate transferase }\end{array}$ & 2 & & Odds Ratio (M-H, Fixed, 95\% Cl) & Subtotals only \\
\hline 1.6.1 6 months & 2 & 10 & Odds Ratio (M-H, Fixed, 95\% Cl) & $0.33[0.02,6.65]$ \\
\hline $\begin{array}{l}1.7 \text { Need for liver transplanta- } \\
\text { tion }\end{array}$ & 3 & & Odds Ratio (M-H, Fixed, 95\% Cl) & Subtotals only \\
\hline 1.7.1 0 to 6 months & 2 & 30 & Odds Ratio (M-H, Fixed, 95\% Cl) & Not estimable \\
\hline 1.7.2 7 to 12 months & 1 & 28 & Odds Ratio (M-H, Fixed, 95\% Cl) & $2.79[0.10,74.63]$ \\
\hline $\begin{array}{l}\text { 1.8 Death related to liver dis- } \\
\text { ease }\end{array}$ & 3 & & Odds Ratio (M-H, Fixed, 95\% Cl) & Subtotals only \\
\hline 1.8 .10 to 6 months & 2 & 30 & Odds Ratio (M-H, Fixed, 95\% Cl) & Not estimable \\
\hline 1.8.2 7 to 12 months & 1 & 28 & Odds Ratio (M-H, Fixed, 95\% Cl) & Not estimable \\
\hline 1.9 Death due to all causes & 3 & & Odds Ratio (M-H, Fixed, 95\% Cl) & Subtotals only \\
\hline 1.9.1 0 to 6 months & 2 & 30 & Odds Ratio (M-H, Fixed, 95\% Cl) & Not estimable \\
\hline 1.9.2 7 to 12 months & 1 & 28 & Odds Ratio (M-H, Fixed, 95\% Cl) & Not estimable \\
\hline 1.10 Change in weight (kg) & 2 & & $\begin{array}{l}\text { Mean Difference (IV, Fixed, 95\% } \\
\mathrm{CI} \text { ) }\end{array}$ & Subtotals only \\
\hline 1.10 .10 to 6 months & 2 & 30 & $\begin{array}{l}\text { Mean Difference (IV, Fixed, 95\% } \\
\text { CI) }\end{array}$ & $-0.90[-1.94,0.14]$ \\
\hline $\begin{array}{l}\text { 1.11 Development of portal hy- } \\
\text { pertension }\end{array}$ & 2 & & Odds Ratio (M-H, Fixed, 95\% Cl) & Subtotals only \\
\hline 1.11 .10 to 6 months & 2 & 30 & Odds Ratio (M-H, Fixed, 95\% Cl) & Not estimable \\
\hline 1.11 .27 to 12 months & 0 & 0 & Odds Ratio (M-H, Fixed, 95\% Cl) & Not estimable \\
\hline $\begin{array}{l}\text { 1.12 Development of complica- } \\
\text { tions of portal hypertension }\end{array}$ & 2 & & Odds Ratio (M-H, Fixed, 95\% Cl) & Subtotals only \\
\hline 1.12 .10 to 6 months & 2 & 30 & Odds Ratio (M-H, Fixed, 95\% Cl) & Not estimable \\
\hline
\end{tabular}




\begin{tabular}{lllll}
\hline Outcome or subgroup title & No. of studies & $\begin{array}{l}\text { No. of partici- } \\
\text { pants }\end{array}$ & Statistical method & Effect size \\
\hline 1.12 .27 to 12 months & 0 & 0 & Odds Ratio (M-H, Fixed, 95\% Cl) & Not estimable \\
\hline
\end{tabular}

Analysis 1.1. Comparison 1: UDCA versus placebo/no additional treatment (all groups given 'conventional care'), Outcome 1: Lack of normalisation of any liver enzyme reported in the trial

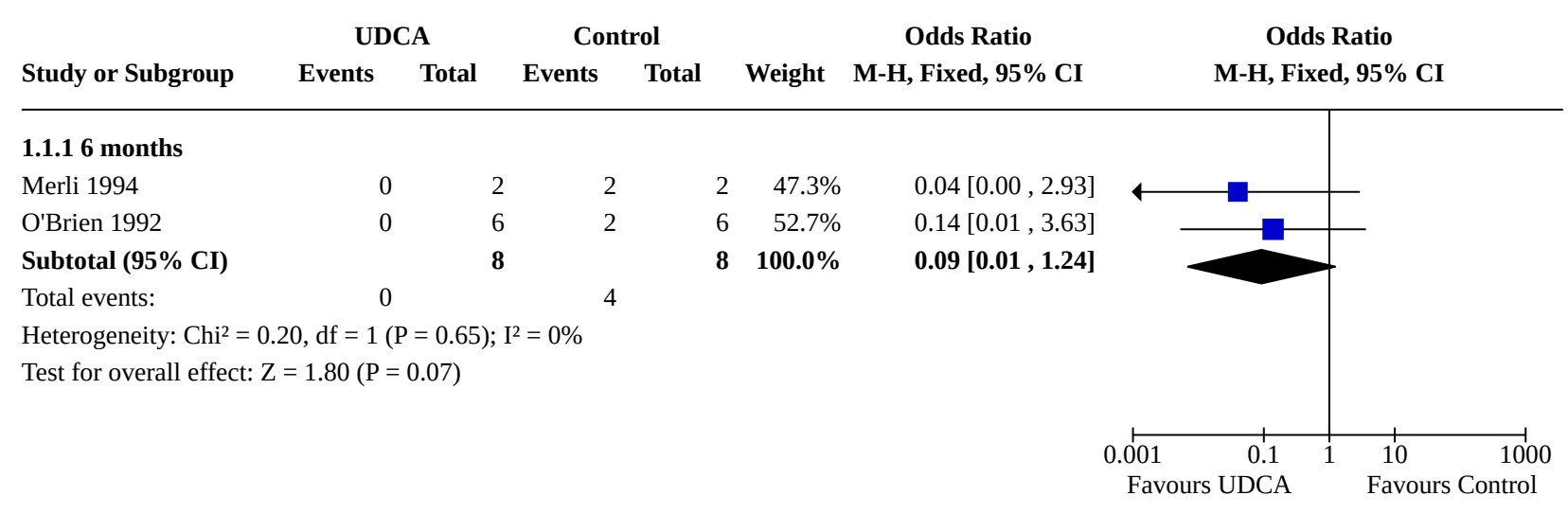

Analysis 1.2. Comparison 1: UDCA versus placebo/no additional treatment (all groups given 'conventional care'), Outcome 2: Lack of normalisation of all liver enzymes reported in the trial

\begin{tabular}{|c|c|c|c|c|c|c|c|}
\hline & \multicolumn{2}{|c|}{ UDCA } & \multicolumn{2}{|c|}{ Control } & \multicolumn{2}{|r|}{ Odds Ratio } & Odds Ratio \\
\hline Study or Subgroup & Events & Total & Events & Total & Weight & M-H, Fixed, 95\% CI & M-H, Fixed, 95\% CI \\
\hline
\end{tabular}

\subsubsection{6 months}

Merli 1994

O'Brien 1992

Subtotal (95\% CI)

Total events:

$\begin{array}{ll}2 & 2 \\ 6 & 6 \\ & 8\end{array}$

$\begin{array}{ll}2 & 2 \\ 6 & 6 \\ & \mathbf{8}\end{array}$

Not estimable

Not estimable

Heterogeneity: Not applicable

Test for overall effect: Not applicable

Not estimable

\section{Analysis 1.3. Comparison 1: UDCA versus placebo/no additional treatment (all groups given 'conventional care'), Outcome 3: Lack of normalisation of 5 ' nucleotidase}

\begin{tabular}{|c|c|c|c|c|c|c|}
\hline & & & Cor & & Odds Ratio & Odds Ratio \\
\hline Study or Subgroup & Events & Total & Events & Total & M-H, Fixed, 95\% CI & M-H, Fixed, 95\% CI \\
\hline
\end{tabular}

\begin{tabular}{|c|c|c|c|c|c|c|}
\hline \multicolumn{7}{|l|}{ 1.3.1 6 months } \\
\hline O'Brien 1992 & 3 & 5 & 3 & 4 & $0.50[0.03,8.95]$ & \\
\hline & & & & & $\begin{array}{lc}0.02 & 0.1 \\
\text { Favours UDCA }\end{array}$ & $\begin{array}{cc}10 & 50 \\
\text { Favours control }\end{array}$ \\
\hline
\end{tabular}


Analysis 1.4. Comparison 1: UDCA versus placebo/no additional treatment (all groups given 'conventional care'), Outcome 4: Lack of normalisation of aspartate transaminase

\begin{tabular}{lccccccc} 
& \multicolumn{2}{c}{ UDCA } & \multicolumn{2}{c}{ Control } & \multicolumn{2}{c}{ Odds Ratio } & Odds Ratio \\
Study or Subgroup & Events & Total & Events & Total & Weight & M-H, Fixed, 95\% CI & M-H, Fixed, 95\% CI
\end{tabular}

1.4.1 6 months Merli 1994

O'Brien 1992

Subtotal (95\% CI)

Total events:

Heterogeneity: Not applicable

Test for overall effect: $\mathrm{Z}=1.45(\mathrm{P}=0.15)$

$\begin{array}{rrrrrr}1 & 1 & 2 & 2 & & \text { Not estimable } \\ 5 & 5 & 3 & 6 & 100.0 \% & 11.00[0.43,284.30] \\ & \mathbf{6} & & \mathbf{8} & \mathbf{1 0 0 . 0 \%} & \mathbf{1 1 . 0 0}[\mathbf{0 . 4 3}, \mathbf{2 8 4 . 3 0}] \\ 6 & & 5 & & & \end{array}$

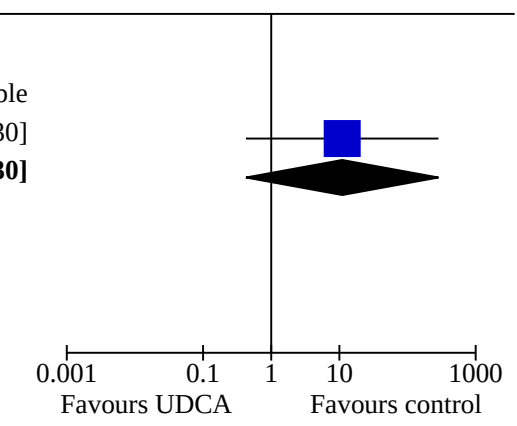

Analysis 1.5. Comparison 1: UDCA versus placebo/no additional treatment (all groups given 'conventional care'), Outcome 5: Lack of normalisation of alanine transferase

\begin{tabular}{lccccccc} 
& \multicolumn{2}{c}{ UDCA } & \multicolumn{2}{c}{ Control } & \multicolumn{2}{c}{ Odds Ratio } & \multicolumn{2}{c}{ Odds Ratio } \\
Study or Subgroup & Events & Total & Events & Total & Weight & M-H, Fixed, 95\% CI & M-H, Fixed, 95\% CI
\end{tabular}

\subsubsection{6 months}

Merli 1994

O'Brien 1992

Subtotal (95\% CI)

Total events:

Heterogeneity: $\mathrm{Chi}^{2}=1.00, \mathrm{df}=1(\mathrm{P}=0.32) ; \mathrm{I}^{2}=0 \%$

Test for overall effect: $\mathrm{Z}=0.76(\mathrm{P}=0.45)$
$0.07[0.00,5.49]$

$1.00[0.05,18.91]$

$0.41[0.04,4.01]$

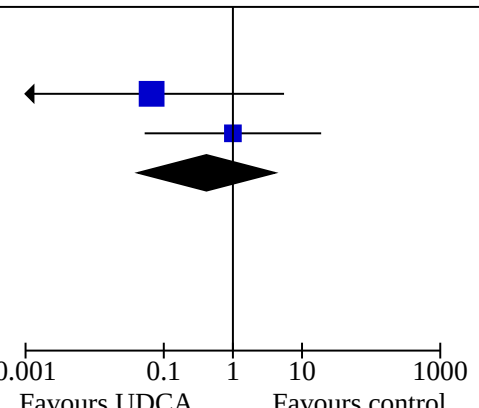

Favours UDCA Favours control

Analysis 1.6. Comparison 1: UDCA versus placebo/no additional treatment (all groups given 'conventional care'), Outcome 6: Lack of normalisation of gammaglutamate transferase

\begin{tabular}{lccccccc} 
& \multicolumn{2}{c}{ UDCA } & \multicolumn{2}{c}{ Control } & \multicolumn{2}{c}{ Odds Ratio } & \multicolumn{2}{c}{ Odds Ratio } \\
Study or Subgroup & Events & Total & Events & Total & Weight & M-H, Fixed, 95\% CI & M-H, Fixed, 95\% CI
\end{tabular}

1.6.1 6 months

Merli 1994

O'Brien 1992

Subtotal (95\% CI)

Total events:

Heterogeneity: Not applicable

Test for overall effect: $\mathrm{Z}=0.72(\mathrm{P}=0.47)$
Not estimable $0.33[0.02,6.65]$ $0.33[0.02,6.65]$ 
Analysis 1.7. Comparison 1: UDCA versus placebo/no additional treatment (all groups given 'conventional care'), Outcome 7: Need for liver transplantation

\begin{tabular}{lccccccc} 
& \multicolumn{2}{c}{ UDCA } & \multicolumn{2}{c}{ Control } & \multicolumn{2}{c}{ Odds Ratio } & \multicolumn{2}{c}{ Odds Ratio } \\
Study or Subgroup & Events & Total & Events & Total & Weight & M-H, Fixed, 95\% CI & M-H, Fixed, 95\% CI
\end{tabular}

1.7.1 0 to 6 months

Merli 1994

O'Brien 1992

Subtotal (95\% CI)

Total events:

$0 \quad 6$

6

$0 \quad 12$

Not estimable

Not estimable

Not estimable

Heterogeneity: Not applicable

Test for overall effect: Not applicable

1.7.2 7 to 12 months

Colombo 1996

Subtotal (95\% CI)

115

$13 \quad 100.0 \%$

$2.79[0.10,74.63]$

Total events:

1

$13 \quad 100.0 \%$

$2.79[0.10,74.63]$

Heterogeneity: Not applicable

Test for overall effect: $\mathrm{Z}=0.61(\mathrm{P}=0.54)$

Analysis 1.8. Comparison 1: UDCA versus placebo/no additional treatment (all groups given 'conventional care'), Outcome 8: Death related to liver disease

\begin{tabular}{lccccccc} 
& \multicolumn{2}{c}{ UDCA } & \multicolumn{2}{c}{ Control } & \multicolumn{2}{c}{ Odds Ratio } & \multicolumn{2}{c}{ Odds Ratio } \\
Study or Subgroup & Events & Total & Events & Total & Weight & M-H, Fixed, 95\% CI & M-H, Fixed, 95\% CI
\end{tabular}

1.8.1 0 to 6 months

Merli 1994

O'Brien 1992

Subtotal (95\% CI)

Total events:

Heterogeneity: Not applicable

Test for overall effect: Not applicable

1.8.2 7 to 12 months

Colombo 1996

$0 \quad 15$

Subtotal (95\% CI)

Total events:

0

15

Heterogeneity: Not applicable

Test for overall effect: Not applicable
Not estimable

Not estimable

Not estimable

Test for overall effect: Not applicable

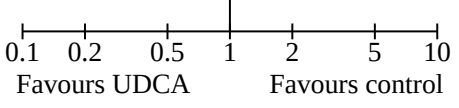


Analysis 1.9. Comparison 1: UDCA versus placebo/no additional treatment (all groups given 'conventional care'), Outcome 9: Death due to all causes

\begin{tabular}{|c|c|c|c|c|c|c|}
\hline \multirow[b]{2}{*}{ Study or Subgroup } & \multicolumn{2}{|c|}{ UDCA } & \multicolumn{2}{|c|}{ Control } & \multirow[b]{2}{*}{ Weight } & \multirow{2}{*}{$\begin{array}{c}\text { Odds Ratio } \\
\text { M-H, Fixed, 95\% CI }\end{array}$} \\
\hline & Events & Total & Events & Total & & \\
\hline \multicolumn{7}{|l|}{ 1.9.1 0 to 6 months } \\
\hline Merli 1994 & 0 & 6 & c & 12 & & Not estimable \\
\hline O'Brien 1992 & 0 & 6 & c & 6 & & Not estimable \\
\hline Subtotal $(95 \% \mathrm{CI})$ & & 12 & & 18 & & Not estimable \\
\hline Total events: & c & & c & & & \\
\hline
\end{tabular}

Heterogeneity: Not applicable

Test for overall effect: Not applicable

1.9.2 7 to 12 months

Colombo 1996

Subtotal (95\% CI)

Total events:

$0 \quad 15$

0

13

Not estimable

0

15

Heterogeneity: Not applicable

Test for overall effect: Not applicable

Odds Ratio

M-H, Fixed, 95\% CI

Analysis 1.10. Comparison 1: UDCA versus placebo/no additional treatment

(all groups given 'conventional care'), Outcome 10: Change in weight (kg)

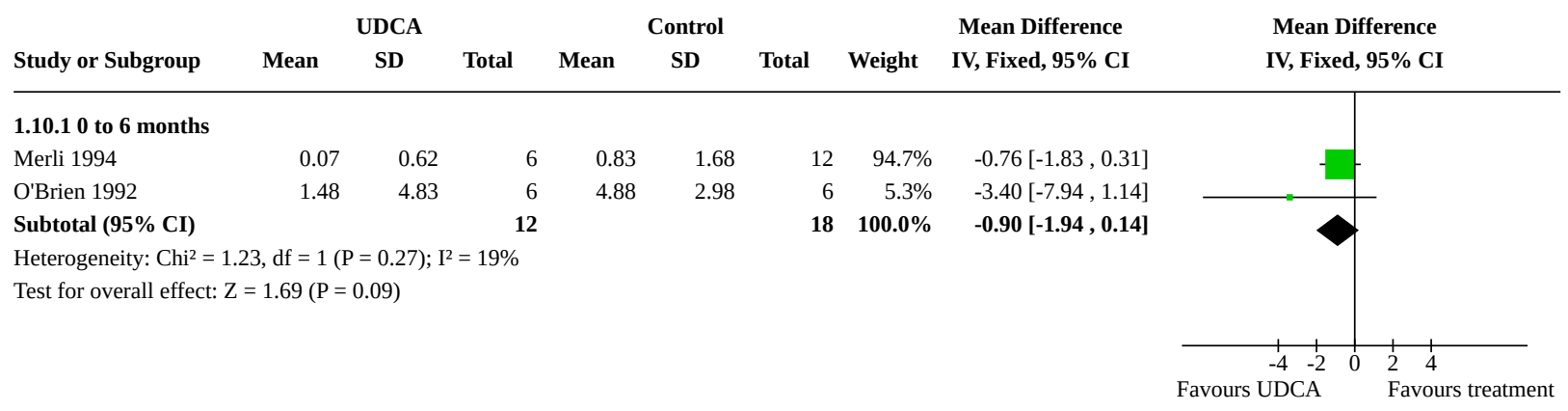


Analysis 1.11. Comparison 1: UDCA versus placebo/no additional treatment (all groups given 'conventional care'), Outcome 11: Development of portal hypertension

\begin{tabular}{|c|c|c|c|c|c|c|}
\hline \multirow[b]{2}{*}{ Study or Subgroup } & \multicolumn{2}{|c|}{ UDCA } & \multicolumn{2}{|c|}{ Control } & \multirow[b]{2}{*}{ Weight } & Odds Ratio \\
\hline & Events & Total & Events & Total & & M-H, Fixed, 95\% CI \\
\hline \multicolumn{7}{|l|}{ 1.11.1 0 to 6 months } \\
\hline Merli 1994 & 0 & 6 & 0 & 12 & & Not estimable \\
\hline O'Brien 1992 & c & 6 & 0 & 6 & & Not estimable \\
\hline Subtotal $(95 \% \mathrm{CI})$ & & 12 & & 18 & & Not estimable \\
\hline Total events: & 0 & & 0 & & & \\
\hline
\end{tabular}

Heterogeneity: Not applicable

Test for overall effect: Not applicable

1.11.2 7 to 12 months

Subtotal (95\% CI)

0

Total events:

0

0

o

Not estimable

Heterogeneity: Not applicable

Test for overall effect: Not applicable

0

Odds Ratio

M-H, Fixed, 95\% CI

\section{Analysis 1.12. Comparison 1: UDCA versus placebo/no additional treatment (all groups given 'conventional care'), Outcome 12: Development of complications of portal hypertension}

\begin{tabular}{|c|c|c|c|c|c|c|c|}
\hline & \multicolumn{2}{|c|}{ UDCA } & \multicolumn{2}{|c|}{ Control } & \multicolumn{2}{|r|}{ Odds Ratio } & Odds Ratio \\
\hline Study or Subgroup & Events & Total & Events & Total & Weight & M-H, Fixed, 95\% CI & M-H, Fixed, 95\% CI \\
\hline
\end{tabular}

1.12.1 0 to 6 months

Merli 1994

O'Brien 1992

Subtotal (95\% CI)

Total events:

Heterogeneity: Not applicable

Test for overall effect: Not applicable

1.12.2 7 to 12 months

Subtotal (95\% CI)

Total events:

0

Heterogeneity: Not applicable

Test for overall effect: Not applicable
Not estimable

Not estimable

Not estimable

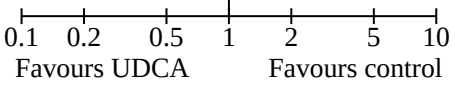




\section{HISTORY}

Protocol first published: Issue 3, 1996

Review first published: Issue 3, 1997

\begin{tabular}{lll}
\hline Date & Event & Description \\
\hline 1 August 2017 & $\begin{array}{l}\text { New citation required but conclusions } \\
\text { have not changed }\end{array}$ & $\begin{array}{l}\text { No new data have been added to this review and hence our con- } \\
\text { clusions remain the same. }\end{array}$ \\
\hline
\end{tabular}

1 August $2017 \quad$ New search has been performed

\begin{abstract}
A search of the Cystic Fibrosis and Genetic Disorders Review Group's Cystic Fibrosis Trials Register identified a single additional reference to an already excluded trial (Colombo 1992). Searches of ongoing trials registries identified two trials which were excluded (NCT00004315; NCT00004441).
\end{abstract}

Three trials were previously listed as 'Studies awaiting classification' pending further information from the authors which we have not been able to access (Kapustina 2000; Lepage 1997; Spray 2000). Two of these trials have never been published as full papers and the abstracts do not contain sufficient details for us to confirm they meet the inclusion criteria; given the age of the abstracts, it is unlikely that any further publications relating to these trials will be forthcoming and they have therefore been excluded (Kapustina 2000; Spray 2000). The third trial is cross-over in design but it is unclear whether there was any washout period employed and data are not published for the first six-month period of the trial (Lepage 1997). We have added the study to the list of included trials, but have not been able to present any results as we are unable to extract appropriate data to analyse.

A summary of findings table has been included.

$\begin{array}{ll}4 \text { December } 2014 & \begin{array}{l}\text { New citation required but conclusions } \\ \text { have not changed }\end{array}\end{array}$

No new information has been added to this review, hence our conclusions remain the same.

4 December $2014 \quad$ New search has been performed

A search of the Cystic Fibrosis \& Genetic Disorders Review Groups' Cystic Fibrosis Trials Register did not identify any new references for inclusion in this review. The format of the plain language summary has been updated.

\begin{tabular}{lll}
\hline 24 January 2013 & Amended & Contact details updated. \\
\hline 12 September 2012 & $\begin{array}{l}\text { New citation required but conclusions } \\
\text { have not changed }\end{array}$ & $\begin{array}{l}\text { No new references have been included in this update of the re- } \\
\text { view and hence the conclusions of the review remain the same. }\end{array}$ \\
\hline 12 September 2012 & New search has been performed & $\begin{array}{l}\text { A new search of the Group's Cystic Fibrosis Trials Register did not } \\
\text { identify any new references potentially eligible for inclusion in } \\
\text { this review. }\end{array}$ \\
\hline 12 August 2010 & New search has been performed & $\begin{array}{l}\text { A search of the Group's Cystic Fibrosis Trials Register did not } \\
\text { identify any new studies for inclusion in this review. }\end{array}$ \\
\hline 11 November 2008 & New search has been performed & $\begin{array}{l}\text { Contact details for Deborah Ashby updated } \\
\text { identify any references which may have been eligible for inclu- } \\
\text { sion in this review. }\end{array}$ \\
\hline
\end{tabular}

Ursodeoxycholic acid for cystic fibrosis-related liver disease (Review) 


\begin{tabular}{lll}
\hline Date & Event & Description \\
\hline 11 November 2008 & Amended & Converted to new review format. \\
\hline 23 May 2007 & New search has been performed & $\begin{array}{l}\text { The Cochrane Cystic Fibrosis and Genetic Disorders Group Tri- } \\
\text { als Register was searched in November 2006 and an additional } \\
\text { reference concerning long-term follow-up data to the already in- } \\
\text { cluded Colombo trial was identified. Follow-up data were only } \\
\text { reported for the whole cohort. }\end{array}$ \\
\hline
\end{tabular}

15 February $2006 \quad$ The Cochrane Cystic Fibrosis and Genetic Disorders Group Trials
Register was searched in November 2005.

No new references were identified in the search.

16 February $2005 \quad$ New search has been performed

The Cochrane Cystic Fibrosis and Genetic Disorders Group Trials Register was searched in November 2004.

No new references were identified in the search.

\begin{tabular}{lll}
\hline 18 February 2004 New search has been performed & The Cochrane Cystic Fibrosis and Genetic Disorders Group Trials \\
& $\begin{array}{l}\text { Register was searched in October 2003. No new references were } \\
\text { identified in the search. }\end{array}$
\end{tabular}

\begin{tabular}{ll}
\hline 19 February $2003 \quad$ Amended & $\begin{array}{l}\text { In January 2003, minor statistical amendments to the data from } \\
\text { the O'Brien } 1992 \text { and Merli } 1994 \text { trials were made. The means } \\
\text { and standard deviations were originally calculated by the re- } \\
\text { viewer from the original published data, but a minor error was } \\
\text { highlighted by the Group's medical statistician and the appropri- } \\
\text { ate corrections undertaken. }\end{array}$
\end{tabular}

\begin{tabular}{ll}
\hline 22 May 2002 New search has been performed & $\begin{array}{l}\text { The Cochrane Cystic Fibrosis and Genetic Disorders Group Trials } \\
\text { Register was searched in April 2002, but no new references were } \\
\text { identified in the search. }\end{array}$ \\
\hline
\end{tabular}

1 May $1999 \quad \begin{aligned} & \text { New citation required and conclusions Substantive amendment } \\ & \text { have changed }\end{aligned}$

\section{CONTRIBUTIONS OF AUTHORS}

Katharine Cheng and Rosalind Smyth independently assessed trials for inclusion in the review. Katharine Cheng wrote the text of the review, assisted by Rosalind Smyth, and acts as guarantor of the review.

Deborah Ashby provided statistical advice.

\section{DECLARATIONS OF INTEREST}

The lead author of this review, Katharine Cheng, has been employed by GlaxoSmithKline Research and Development Ltd since late 2004. GlaxoSmithKline does not produce or market any drugs that may fall into the scope of this review.

Deborah Ashby and Rosalind Smyth declare no potential conflicts of interest.

\section{SOURCES OF SUPPORT}

\section{Internal sources}

- No sources of support supplied

\section{External sources}

- NHS North West Region R\&D Programme, UK 


\section{DIFFERENCES BETWEEN PROTOCOL AND REVIEW}

In a post hoc change, in line with current Cochrane guidance, at the 2017 update we added a summary of findings table with seven outcomes chosen based on relevance to clinicians and consumers.

\section{INDEX TERMS}

\section{Medical Subject Headings (MeSH)}

Bile [metabolism]; Cholagogues and Choleretics [ ${ }^{*}$ therapeutic use]; Chronic Disease; Cystic Fibrosis [ ${ }^{*}$ complications]; Liver [enzymology]; Liver Diseases [etiology] [*prevention \& control]; Nutritional Status; Randomized Controlled Trials as Topic; Ursodeoxycholic Acid [ ${ }^{*}$ therapeutic use]

\section{MeSH check words}

Adolescent; Adult; Child; Child, Preschool; Humans 